\title{
The detrital zircon record of an Archaean convergent basin in the Southern São Francisco Craton, Brazil
}

\author{
Hugo Moreira, Cristiano Lana*, Hermínio Arias Nalini Jr. \\ Applied Isotope Research Group, Departamento de Geologia, Universidade Federal de Ouro Preto, Ouro Preto, MG 35400000, Brazil
}

\section{A R T I C L E I N F O}

\section{Article history:}

Received 31 July 2015

Received in revised form

14 December 2015

Accepted 16 December 2015

Available online 29 December 2015

\section{Keywords:}

São Francisco Craton

Rio das Velhas

Maquiné Group

Detrital zircons

Greenstone belt

Convergent basin

\begin{abstract}
A B S T R A C T
Detrital zircon ages are an important tool to study the provenance and evolution of sedimentary rocks, and currently there is a general lack of such studies in greenstone belt basins. In this paper, we combine field observations and in situ U-Pb/Lu-Hf detrital zircon analyses to constrain the evolution of a large, ancient convergent basin in SE Brazil. The Maquiné Group (the uppermost clastic sequence of the Rio das Velhas Greenstone Belt) was deposited during a fundamental shift in the evolution of the southern São Francisco Craton that ended with closure of the greenstone belt basin and the stabilization of the continental crust at ca. 2730-2700 Ma. We show that detritus accumulated in the Maquiné basin derived from uplifted nearby source rocks and that sedimentation was marked by drastic upward lithological changes (from flysch to molasse-type sedimentation). The restricted distributary provenance (marked by a strong uni-modal age spectra at 2770-2780 Ma) requires that sedimentation was concomitant with exhumation of a proximal 2770-2780 Ma TTG magmatic arc. The entire detrital zircon spectra show that maximum deposition ages are very close to the timing of deposition, and confirm that deposition occurred during or immediately after tectonic convergence. Variations in $\varepsilon \mathrm{Hf}_{(\mathrm{t})}$ values support the idea that the Archaean crystalline crust of the craton was built by crust-mantle mixing processes with a successive decrease of values in zircons crystallized after $3100 \mathrm{Ma}$. In a regional context, our dataset supports previous interpretations of a long-lived evolution of the southern São Francisco Craton comprising a succession of magmatic arcs and Archaean convergent basins.
\end{abstract}

(C) 2016 Elsevier B.V. All rights reserved.

\section{Introduction}

Zircon is a minor component in sedimentary rocks but is an important mineral in studies of provenance, determination of maximum deposition ages, tectonic evolution of sedimentary basins and magmatic processes of continents (e.g., Fedo et al., 2003; Andersen, 2005; Dickinson and Suczek, 1979; Garzanti et al., 2007; Condie et al., 2009; Hawkesworth et al., 2010; Cawood et al., 2007, 2012). When accurately correlated with age of deposition, detrital zircon ages make a sensitive discriminator of the tectonic environment from which sediments were generated (Hawkesworth et al., 2009). Two variables control the age distribution spectra of detrital zircons: (1) the presence or absence of syn-sedimentary magmatic activity and (2) the overall spread and proportion of different ages recorded (Cawood et al., 2013). For example, large quantities of igneous zircons with ages close to the timing of sedimentation reflect syn-depositional magmatic activity, which only takes place

\footnotetext{
* Corresponding author. Tel.: +55 3198483538.

E-mail address: cristianodeclana@gmail.com (C. Lana).
}

at convergent boundaries of tectonic plates. Nearly half the zircons accumulated in convergent environments such as fore-arcs, trenches and back-arc basins are likely to record ages contemporary with the age of deposition, whereas $30 \%$ of the remaining zircons will have a small age difference between crystallization and time deposition (e.g., less than $100 \mathrm{Ma}$ ). Basins developed in collisional environments will contain $10-50 \%$ of detrital zircons with ages around $150 \mathrm{Ma}$ older than the timing of deposition whereas extensional basins (e.g., passive margin basins) will have zircons that are much older. The largest gaps between zircon age and depositional age are observed in extensional environments and reflect the lack of magmatism or the type of magmatic rocks (generally zircon-poor) during extension (Storey, 1995; Cawood et al., 2012).

The application of detrital zircon age spectra to constrain tectonic settings can be particularly useful for old, deformed greenstone belt basins, which had their sedimentological record partly destroyed by younger tectonic events. Detailed reconstructions of individual greenstone belts may vary widely and are frequently biased towards the younger magmatic/metamorphic record of the surrounding crystalline crust (Anhaeusser, 2014). Several examples in the literature have shown that the detrital zircon record, 


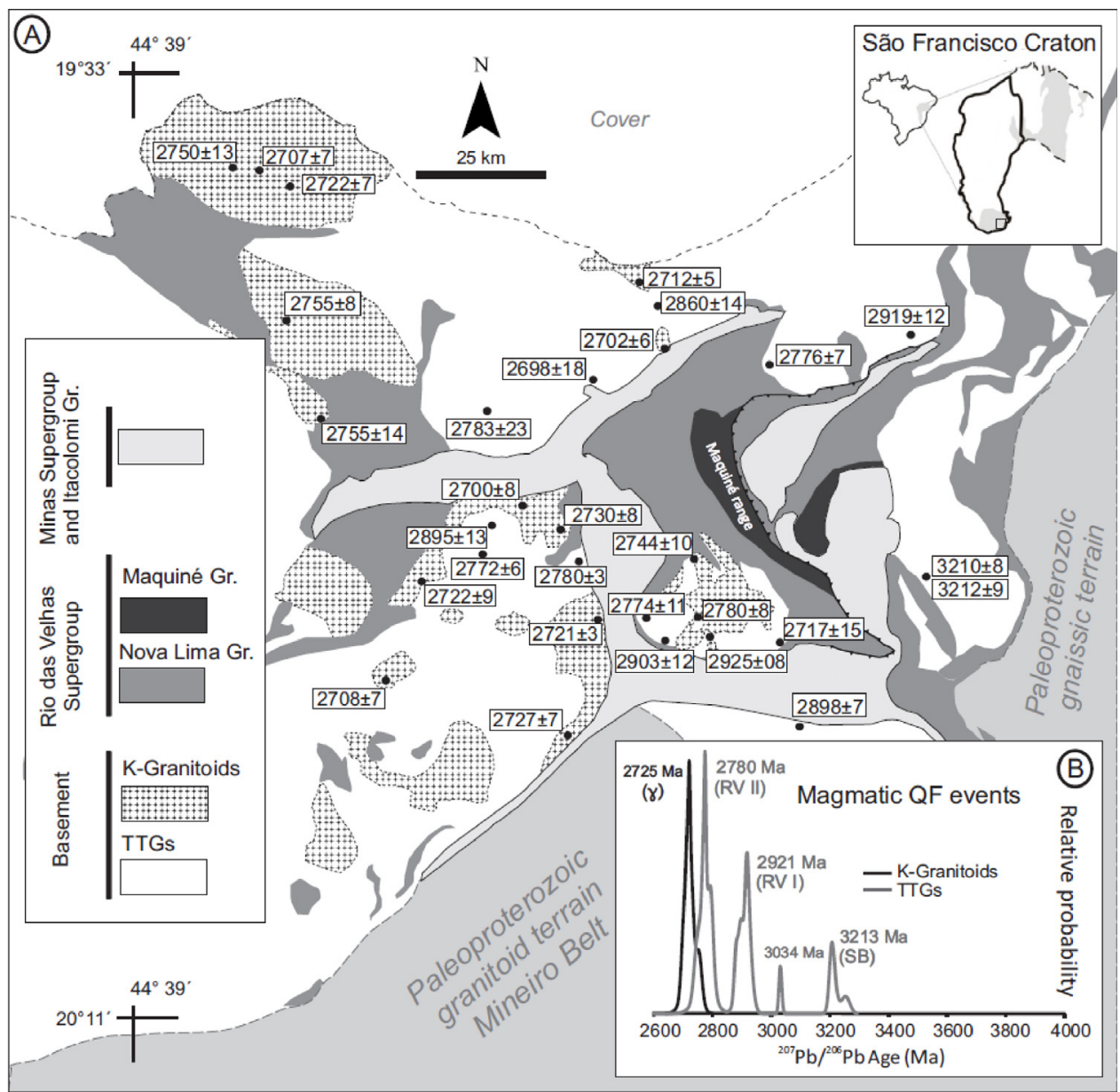

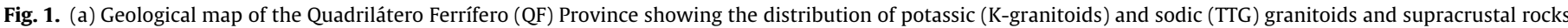

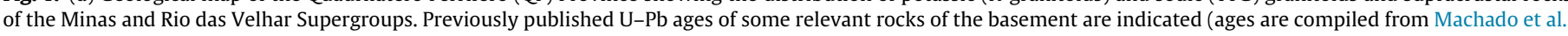

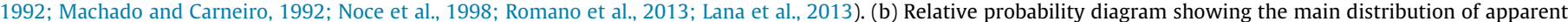

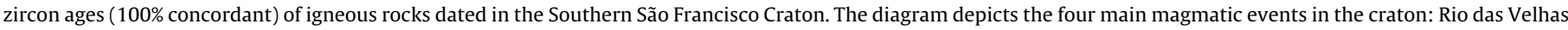
I (RV I); Rio das Velhas II (RV II), Santa Bárbara (SB) and Potassic Granitoids ( $\gamma$ - also known as Mamona event, Farina et al., 2015).

in conjunction with field-based stratigraphic observations, can provide useful information on the depositional environment and on the tectonics of the source (e.g., Davis, 2002; Kositcin and Krapež, 2004; Condie et al., 2009; Kaur et al., 2013; Lancaster et al., 2014; Gehrels, 2014; Zeh et al., 2014).

This study focuses on the detrital zircon record of the Maquiné Range: South America's largest and best-preserved sequence of Neoarchaean metasedimentary rocks. The Range is $40 \mathrm{~km}$ long, and about 2-4 km wide (Menezes, 1988), forming a long strip of molasse sediments at the heart of the Rio das Velhas Greenstone Belt, southern São Francisco Craton (SSFC) (Fig. 1a)(Dorr, 1969). The antiquity and tectonic setting of the crystalline crust that surrounds the Maquiné Range have been investigated in a number of studies which propose a polyphase magmatic evolution, including three main periods of Tonalite-Trondhjemite-Granodiorite (TTG) magmatism and tectonic accretion of greenstone belt mafic/ultramafic crust (e.g., Romano, 1989; Machado et al., 1992; Machado and Carneiro, 1992; Teixeira et al., 1996; Noce et al., 1998; Romano et al., 2013; Lana et al., 2013). The deposition of the Maquiné sediments is an essential part of this history, because it records the final period of tectonic/magmatic activity prior to the stabilization of the Archaean craton at $2700 \mathrm{Ma}$. Given the regional context and its stratigraphic position within the greenstone belt, the Maquiné Range is a key record of the early magmatic evolution of Archaean TTG crust in South America. In addition, understanding the timing and environment of deposition for the Maquiné Group can elucidate several aspects about the tectonic evolution of the Rio das Velhas Greenstone Belt (Fig. 1a).

We combine stratigraphic observations and $\mathrm{U}-\mathrm{Pb}$ analysis from the Maquiné Range to clarify several aspects of the tectonic evolution of southern São Francisco Crust. Key issues are: (1) the source of sediments and environment of deposition of the range, not previously discussed; (2) implications of the detrital zircon ages to the understanding of magmatic events in the craton, and; (3) tectonic setting that prevailed during deposition of the sedimentary sequence. Additionally we provide Lu-Hf isotopes from 343 detrital zircons in order to delimit part of the magmatic evolution of the crust.

\section{Geological setting}

The Quadrilátero Ferrífero (QF) is located in the easternmost part of the Southern São Francisco Craton (SSFC). It is conventionally subdivided into Archaean crystalline TTG/calc-alkaline crust and Archaean to Palaeoproterozoic supracrustal strata. The TTG/calc-alkaline crust was built during three main periods of magmatic activity and tectonic accretion (Lana et al., 2013). The first period, named the Santa Bárbara event (SB; 3220-3200 Ma) (Fig. 1b), gave rise to the Palaeoarchaean core of the SSFC via juvenile TTG magma injections in mafic-ultramafic greenstone belt crust. The second magmatic period, the Rio das Velhas I event (RV I; 
2930-2900 Ma) (Fig. 1b), is recorded throughout the SSFC by successive TTG intrusions and tectonic accretions of island arcs. The last magmatic period, the Rio das Velhas II (RV II; 2800-2770 Ma) (Fig. 1b), took place around the margins of the RV I continental crust through arc related magmatism and extrusion of felsic lavas in the main greenstone belt sequence. The TTG crust was later injected by voluminous potassic granitoids that represent about $30 \%$ of the Archaean basement in the SSFC (Romano et al., 2013), termed the Mamona event (Farina et al., 2015). The bulk of the potassic granitoid batholiths were emplaced between 2750 and $2700 \mathrm{Ma}$. However, small bodies record ages at around $2612 \mathrm{Ma}$.

The TTG/calc-alkaline crust is in fault/tectonic contact with Rio das Velhas Greenstone Belt of Archaean age. The belt is subdivided into a marine basal sequence named the Nova Lima Group and nearshore, non-marine clastic sediments of the Maquiné Group. The base of the Nova Lima Group consists of a mafic-ultramafic volcanic association (metabasalts and metakomatiites) interlayered (towards the top) with banded iron formations, chert and carbonaceous pelites and felsic volcanoclastic rocks that were emplaced at $2792 \pm 11,2773 \pm 7$ and $2751 \pm 9 \mathrm{Ma}$ (Noce et al., 2005). These volcanic rocks are interbedded with marine shales and phyllites that grade into sandy phyllites, quartzites and conglomerates of the Maquiné Group.

Early geological mapping in the SSFC has subdivided the Maquiné Group into the Palmital (O’Rourke, 1957) and Casa Forte (Gair, 1962) formations. The Palmital Formation comprises marine/subaerial shales and phyllites which are interpreted as distal turbidites (Baltazar and Zucchetti, 2007), whereas the Casa Forte Formation constituted non-marine conglomeratic quartizites, which are interpreted as longitudinal bars or proximal portions of an alluvial fan. Some conglomerates seem to represent distal portions of a braided river system associated with alluvial fans (Baltazar and Zucchetti, 2007). Based on structural, lithological and facies characteristics, Baltazar and Zucchetti (2007) interpreted the Palmital Formation as part of the Nova Lima Group. This is mainly because of the gradational contact with the top of the Nova Lima shales and phyllites. They proposed that sediments of the Nova Lima and the Maquiné Group were deposited during the early stages of subduction and closure of a flysch to molasse basin (see also Dorr, 1969). U-Pb ages (ID-TIMS) of five detrital zircons belonging to the Palmital Formation (Machado et al., 1996) led previous authors to conclude that the main source for the detrital sequences of the Rio das Velhas Supergroup is older than the magmatic event RV II (Machado and Carneiro, 1992). However, the limited number of zircons dated did not allow further investigations of the maximum age of deposition and other possible sources.

The Rio das Velhas Greenstone Belt sequence is overlain by an intracratonic sedimentary sequence known as the Minas Supergroup, which was deposited after stabilization of the craton at ca. $2700 \mathrm{Ma}$ (Romano et al., 2013). According to Alkmim and Marshak (1998), the Minas sequence records the complete development a Wilson Cycle between 2500 and 2000 Ma. From the base to the top it is divided into Tamanduá/Caraça, Itabira, Piracicaba and the Sabará groups. The Tamanduá/Caraça Group comprises sandstones and conglomerates representing the rift phase of the basin. The sediments record a maximum age of deposition of ca. $2600 \mathrm{Ma}$ (Machado et al., 1996; Hartmann et al., 2006.). The Itabira Group consists of banded iron formation within the Cauê Formation and the carbonate rocks within the Gandarela Formation (ca. 2420 Ma - Babinski et al., 1995) corresponding to development of a passive margin during a period of tectonic quiescence (Renger et al., 1995). The Piracicaba Group consists of quartzite and ferruginous shales, conglomerates with pebbles of itabirite and carbonaceous phyllites that were deposited in a shallow to deep marine environment; and, like the Tamanduá and Caraça Groups, it contains zircons from the TTGs and potassic granitoids of the basement (Machado et al., 1996; Mendes et al., 2014). The Sabará Group is composed of syn-orogenic deposits accumulated in a foreland basin and thus marks the tectonic inversion of the Minas Basin (Renger et al., 1995; Alkmim and Marshak, 1998) with maximum deposition age at ca. $2100 \mathrm{Ma}$ (Machado et al., 1996). The Minas Supergroup is capped by polymictic conglomerates, sericitic quartzites and pelites from the Itacolomi Group, that are interpreted as intramontane detritus accumulated during the collapse phase following the Palaeoproterozoic Transamazonian orogeny at ca. $2100 \mathrm{Ma}$ (Alkmim and Marshak, 1998; Farina et al., 2015) (Fig. 2).

\section{Methodology}

Zircons were separated from rock samples for $\mathrm{U}-\mathrm{Pb}$ and $\mathrm{Lu}-\mathrm{Hf}$ analyses at the Department of Geology (DEGEO), Universidade Federal de Ouro Preto, Brazil. The zircon extraction technique makes use of jaw crusher, milling, manual panning, heavy liquids separation, hand-picking under a binocular microscope and mounting on $25 \mathrm{~mm}$ epoxy (SpeciFix) mounts. Mounts were polished and imaged under SEM-cathodoluminescence (CL) in a JEOL 6510 Scanning Electron Microscope hosted at DEGEO.

One thousand four hundred thirty-three (1433) U-Pb analyses of zircon grains were carried out in an Agilent 7700x quadrupole ICP-MS coupled to a 213 NdYAG laser (New Wave Research UP-213) housed at DEGEO (Supplementary data - Table 1). The standard and unknown zircons were ablated in a small volume (tear-drop shape) sample cell, with an insert that holds one 25-mm-diameter sample mount and a 7-mm-diameter standard mount. Acquisitions consisted of a $20 \mathrm{~s}$ measurement of the gas blank, followed by a $40 \mathrm{~s}$ measurement of $\mathrm{U}$, Th and $\mathrm{Pb}$ signals during ablation, and a 30 s washout (e.g., Lana et al., 2010a, 2013; Buick et al., 2011). Mounts were acid-washed before being analyzed to remove possible surface $\mathrm{Pb}$ contamination. Laser ablations were performed at $30 \mu \mathrm{m}$ spot size, $6-8 \mathrm{~J} / \mathrm{cm}^{2}$ fluence and $10 \mathrm{~Hz}$ repetition rate. Ablations were carried out using He as a carrier gas mixed with Ar prior to introduction into the ICP-MS. Integration times were $15 \mathrm{~ms}$ for ${ }^{206} \mathrm{~Pb}$ and ${ }^{238} \mathrm{U}, 40 \mathrm{~ms}$ for ${ }^{207} \mathrm{~Pb}$ and $10 \mathrm{~ms}$ for ${ }^{208} \mathrm{~Pb} ;{ }^{204} \mathrm{~Pb}+{ }^{204} \mathrm{Hg}$ and ${ }^{232} \mathrm{Th}$. Protocols for the U-Pb analyses are described in Takenaka et al. (2015). As primary reference material we used the GJ-1 zircon (608 $\pm 1 \mathrm{Ma}$; Jackson et al., 2004) and for quality control we used the Plešovice zircon (337 $\pm 1 \mathrm{Ma}$; Sláma et al., 2008) as a secondary standard. Some six hundred analyses of the GJ-1 zircon standard gave mean ages of $609 \pm 27 \mathrm{Ma}\left({ }^{207} \mathrm{~Pb} /{ }^{206} \mathrm{~Pb}\right), 602 \pm 4 \mathrm{Ma}\left({ }^{206} \mathrm{~Pb} /{ }^{238} \mathrm{U}\right)$ and $603 \pm 5 \mathrm{Ma}$ $\left({ }^{207} \mathrm{~Pb} /{ }^{235} \mathrm{U}\right)$. One hundred and forty eight analyses of the Plešovice standard gave mean ages of $341 \pm 32 \mathrm{Ma}\left({ }^{207} \mathrm{~Pb} /{ }^{206} \mathrm{~Pb}\right) ; 332 \pm 2 \mathrm{Ma}$ $\left({ }^{206} \mathrm{~Pb} /{ }^{238} \mathrm{U}\right)$ and $333 \pm 4 \mathrm{Ma}\left({ }^{207} \mathrm{~Pb} /{ }^{235} \mathrm{U}\right)$. See supplementary data for detailed information (Table 2). Signal data were reduced using the software Glitter (van Achterbergh et al., 2001) and age distribution diagrams were constructed using the Excel Isoplot program (Ludwig, 2003).

Forty-two U-Pb analyses were also carried out using a ThermoFinnigan Element 2 sector field ICP-MS coupled to a CETAC 213 ultraviolet laser system (LA-SF-ICP-MS) at DEGEO (Supplementary data - Table 3). Thirty-two analyses were performed directly on the same spot or on the same domain to previous $\mathrm{U}-\mathrm{Pb}$ analyses described above to compare the precision between the instruments. Data were acquired in peak jumping mode during $20 \mathrm{~s}$ background measurement followed by 20 s sample ablation - spot size $20 \mu \mathrm{m}$. Data were corrected for background signal, common $\mathrm{Pb}$, laser-induced elemental fractionation, instrumental mass discrimination, and time-dependent elemental fractionation of $\mathrm{Pb} / \mathrm{U}$ using a MS Excel spreadsheet program (Gerdes and Zeh, 2006). The common- $\mathrm{Pb}$ correction was based on the $\mathrm{Pb}$ composition model (Stacey and Kramers, 1975). Laser-induced elemental fractionation 


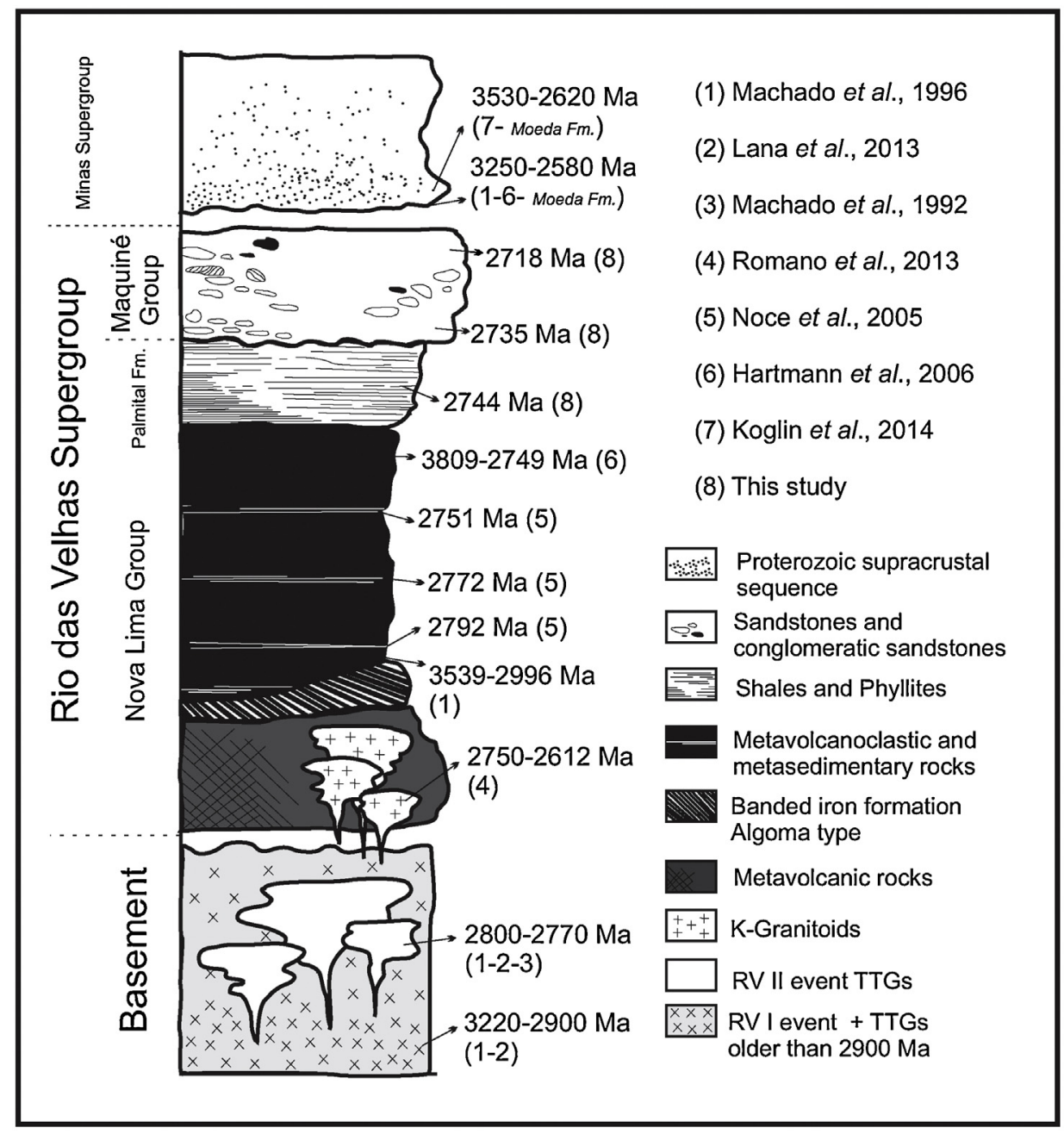

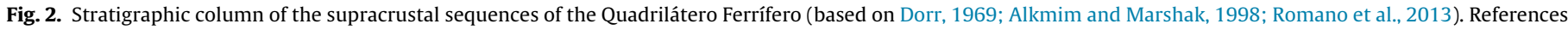
to the age data are listed in the figure by the numbers in parentheses.

and instrumental mass discrimination were corrected by normalization to the reference zircon GJ-1 (Jackson et al., 2004) and zircon Plešovice (Sláma et al., 2008). Results show high accuracy and are identical to those previously generated by LA-Q-ICP-MS. See supplementary data for details.

Zircons that were $>10 \%$ discordant were discarded. According to Gehrels (2011) a figure of $>10 \%$ should be used as a tight discordance cutoff with the ideal situation being use of only concordant ages. $\mathrm{U} / \mathrm{Th}<0.1$ zircons also were not used which may indicate metamorphic ages (e.g., Hartmann and Santos, 2004; Rubatto, 2002). Such characteristics do not fit the goal of sedimentary provenance of the present work and therefore those zircons are not present in the supplementary data.

Lu-Hf analyses were carried out at DEGEO using a Thermo-Finnigan Neptune multicollector ICP-MS coupled to a Photon-Machines $193 \mathrm{~nm}$ excimer laser system (LA-MC-ICP-MS), following the methods of Gerdes and Zeh (2006, 2009). Data (343 analyses, Supplementary data - Table 4) were collected in static mode during $60 \mathrm{~s}$ of ablation with a spot size of $50 \mu \mathrm{m}$. The spots were drilled with a repetition rate of $6 \mathrm{~Hz}$. Typical signal intensity was ca. $10 \mathrm{~V}$ for ${ }^{177} \mathrm{Hf}$. The isotopes ${ }^{172} \mathrm{Yb},{ }^{173} \mathrm{Yb}$ and ${ }^{175} \mathrm{Lu}$ were simultaneously monitored during each analysis step to allow for correction of isobaric interferences of $\mathrm{Lu}$ and $\mathrm{Yb}$ isotopes on mass 176 . The accuracy and external reproducibility were verified by analyses of the standard zircons GJ-1 (Jackson et al., 2004), Plešovice (Sláma et al., 2008), Temora (Black et al., 2003; Wu et al.,
2006), Mud Tank (Black and Gulson, 1978; Woodhead and Hergt, 2005), Blue Berry (Santos et al., 2016) which yielded ${ }^{176} \mathrm{Hf} /{ }^{177} \mathrm{Hf}$ of $0.282015 \pm 0.000019 \quad(n=74), 0.282483 \pm 0.000017 \quad(n=16)$, $0.282683 \pm 0.000019 \quad(n=73), \quad 0.282505 \pm 0.000017 \quad(n=26)$, $0.281677 \pm 0.000017(n=11)$ respectively (all errors are $\pm 2 \sigma \mathrm{SD}$ ). These ratios are in good agreement with the accepted ratios data of $0.282000 \pm 0.000005$ (GJ-1), $0.282482 \pm 0.000013$ (Plešovice), $0.282680 \pm 0.000031$ (Temora), $0.282504 \pm 0.000044$ (Mud Tank) and $0.281674 \pm 0.000018$ (Blue Berry). See supplementary data for detailed information (Table 5 ).

\section{Field observations}

The Maquiné Range is bound on either side by shales and schists of the Nova Lima Group (Fig. 3). These shales and schists are predominantly fine grained and display a waxy texture due to high concentrations of white mica and clay materials. They are distinguished from the Maquiné units because of their clay-rich composition as opposed to quartzose composition of the Palmital phyllites and schists. Our field observations and stratigraphic logging (along 4 profiles across the range) allowed the subdivision of the Maquiné Group into three main stratigraphic sequences (Sequences 1-3) (Fig. 4). These sequences are laterally continuous and record their own set of facies and detrital zircon assemblages (described below). 


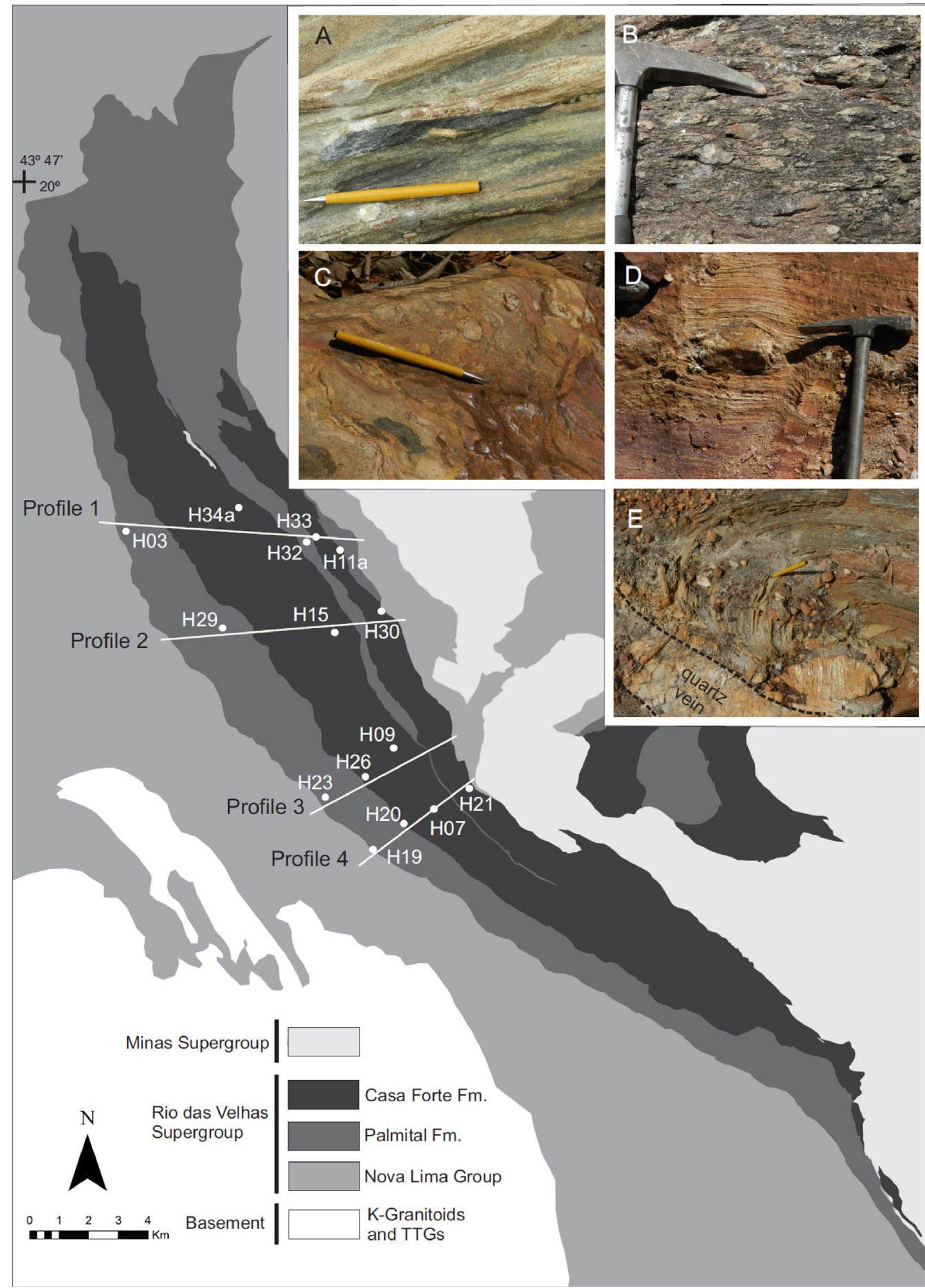

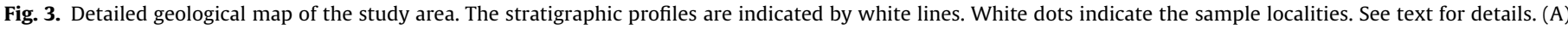

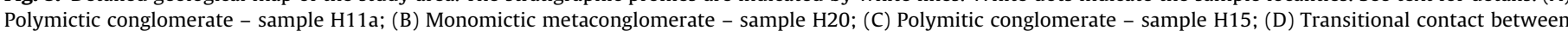

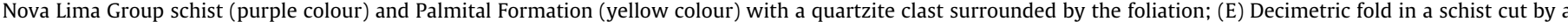
quartz vein. (For interpretation of the references to colour in this figure legend, the reader is referred to the web version of this article.)

Sequence 1 (Fig. 4) belongs entirely to the Palmital Formation with an estimated thickness between 900 and $1600 \mathrm{~m}$. The lower portion of Sequence 1 consists of biotite-sericite-quartz schists, quartz-sericite-schist and minor layers of phyllite and carbonaceous phyllite (e.g., Fig. 5e and f). Some phyllite layers exhibit decussate kyanite prisms a few millimetres in length. The lower contact with the schists of the Nova Lima Group is often gradational, but locally an angular unconformity is present (e.g., Fig. 3d).
Towards the top, ferruginous sandstones with decimetric to centimetric clasts are intercalated with schists and phyllites.

Sequence 2 (Fig. 4) is in sharp contact with the underlying sequence. It consists of a $2000 \mathrm{~m}$ thick sequence of alternating quartzite, and monomict and polymict conglomerates (e.g., Figs. 3b, c; and 5b, c, d). For most parts, the quartzite is sheared, but compact/massive varieties are also present. They may contain sparse quartz pebbles and are intercalated with 


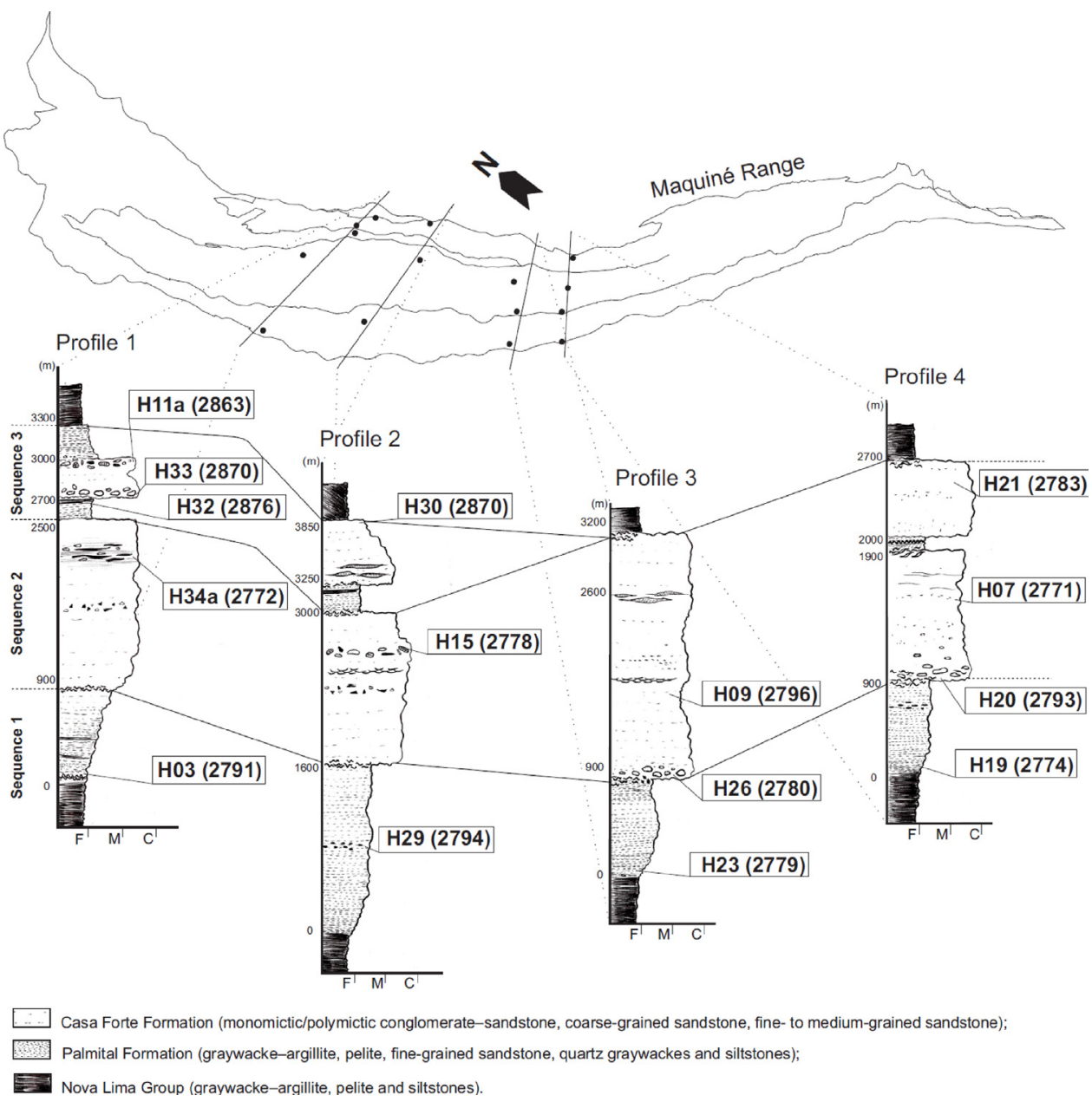

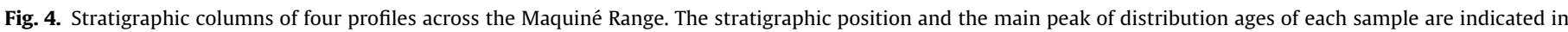
millions of years in parentheses.

rather homogeneous greywackes. Locally, fine- to medium-grained quartzites alternate with conglomerate lenses that change in composition and thickness along strike, from NW to SE. Conglomerate cobbles reach up to $25 \mathrm{~cm}$ in diameter and display a range of compositions including banded iron formations, carbonaceous schists, quartzites, mafic rocks, granites and quartz veins (e.g., Fig. 3a and c). The monomict conglomerate occurs in two ways: with quartz pebbles of various sizes (up to $10 \mathrm{~cm}$ in diameter) (e.g., Fig. 3b) or with phyllitic lenses (and cobbles) that are stretched parallel to the regional foliation (e.g., Fig. 5g). Phyllite and quartz pebbles occur throughout the sequence, but those consisting of iron-formation are much more abundant in the northern part of the range.

Sequence 3 (profiles 1 and 2) (Fig. 4) averages $800 \mathrm{~m}$ in thickness and displays a more complex arrangement of lithologies that is not present in Sequences 1 and 2. Phyllites and shales occur at the top and bottom of the sequence, bounding on either side a package of conglomerates and quartzites. This arrangement has been interpreted previously as an intercalation of Casa Forte and Palmital Formations (Dorr, 1969); however, further stratigraphic studies are needed to constrain the nature of this sequence. We observed that the monomict and polymict conglomerates contain quartz and iron formation pebbles suggesting a similar source to that of the Casa Forte Formation of Sequence 2. Shales and phyllites are identical to those of the Palmital Formation in Sequence 1; however, they are strongly folded and associated with quartz veins (Fig. 3e).

\section{Samples and $\mathrm{U}-\mathrm{Pb}$ geochronology}

Samples from the Maquiné Group (15 samples) were collected along four profiles across the mountain range (Fig. 3). Dating of this sedimentary sequence not only allows the study of sedimentary provenance, but also reveals evidence of Palaeoarchaean crustal segments that have not yet been identified in the field. The large number of samples is justified by the significant geochronological variability of the crystalline basement. In this study, nearly five hundred zircon ages were obtained from five samples of Palmital Formation and more than nine hundred zircons ages were obtained from 10 samples of Casa Forte Formation (see Supplementary Data A - Table 1 - for the $\mathrm{U}-\mathrm{Pb}$ results).

Detrital zircon grains are mostly rounded. Some grains are subhedral and the presence of broken fragments is commonplace. The grains vary in colour from translucent to brown and the length of individual grains varies between 50 and $300 \mu \mathrm{m}$. CL images (Fig. 6) showed that most of the zircon grains have oscillatory zoning. Some zircons are unzoned, internally structureless or sector zoned. Relationships between certain shapes, internal $\mathrm{CL}$ images and $\mathrm{U}-\mathrm{Pb}$ have not been detected clearly although generally bigger grains have presented older ages (Fig. 6).

Samples of Sequence 1 (H19, H23, H29, H03) have very similar age patterns, each of which have one dominant peak between $2779 \mathrm{Ma}$ and $2802 \mathrm{Ma}$ (see Supplementary Data B for a detailed description of the individual samples). Subordinate peaks 

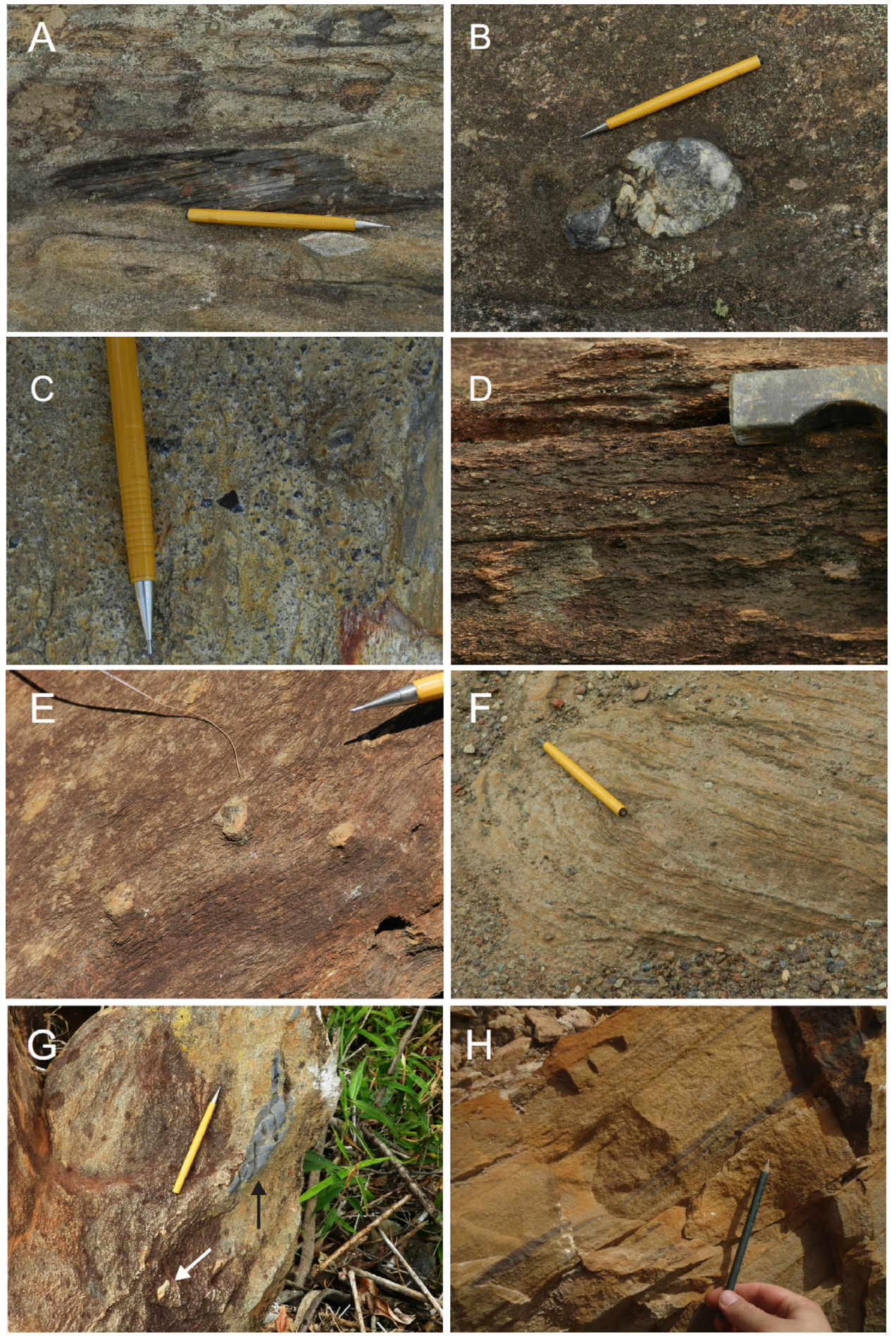

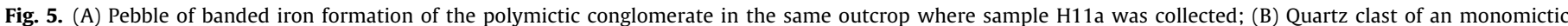

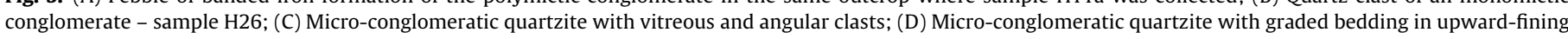

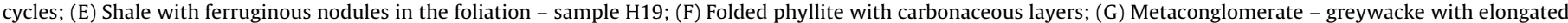
clasts of quartz (white arrow) and phyllite (black arrow) - sample H34a; (H) Quartzite with centimetric ferruginous grey layers - sample H7.

( $<10$ zircons) between $3200 \mathrm{Ma}$ and $3400 \mathrm{Ma}$ and at $2870 \mathrm{Ma}$ and $2930 \mathrm{Ma}$ are observed (Fig. $7 \mathrm{a}$ - Sequence 1), but demonstrably the largest contribution of grains come from the RV II (2770-2800 Ma) rocks. Samples from Sequence 2 (H34a, H15, H09, H07, H21, H26, H20) record a similar uni-modal pattern to those of Sequence 1, with even larger peaks between 2770 and 2800 Ma and smaller peaks at 2855 and 2880 and $3070 \mathrm{Ma}$ (Fig. $7 \mathrm{~b}$ - Sequence 2 ). Samples from Sequence 3 (H30, H11a, H33, H32) record strikingly different patterns with a wide range of prominent peaks at $2870 \mathrm{Ma}$, $3030 \mathrm{Ma}, 3230 \mathrm{Ma}, 3320 \mathrm{Ma}$. In contrast to those of Sequences 1 and 2, samples H11a, H33, H32 record only subordinate peaks ( $<10$ zircons) between 2770 and $2800 \mathrm{Ma}$, suggesting a drastic change 


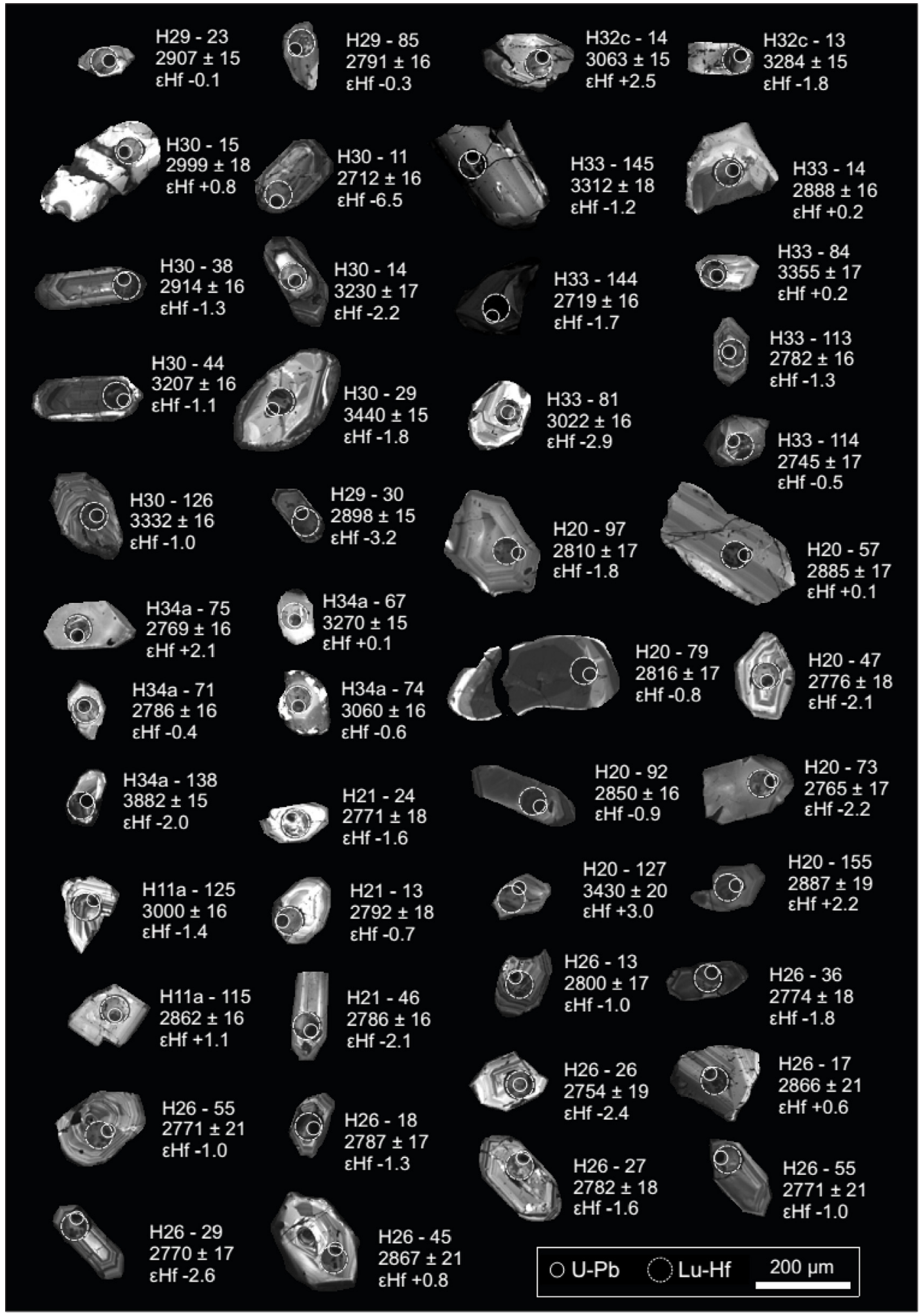

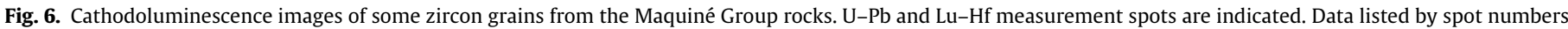
are available in the supplementary data file. Note the variety of grain sizes, shapes, internal structures, ages and source magma signatures ( $\varepsilon \mathrm{Hf}_{(\mathrm{t})} \mathrm{values}_{\mathrm{f}}$.

in source from RV II rocks to a wider range of older basement rocks ranging in age from 2900 to $3500 \mathrm{Ma}$ (Fig. 7c - Sequence 3). Samples from Sequence 3 also display considerable smaller peaks at ca. $2700 \mathrm{Ma}$ (mainly H30) indicating a small but relevant contribution of younger rocks.

\section{Lu-Hf isotope analyses}

The initial ${ }^{176} \mathrm{Hf} /{ }^{177} \mathrm{Hf}$ ranges from 0.280204 to 0.281078 (Fig. 8a) and was calculated on the basis of the measured ${ }^{207} \mathrm{~Pb} /{ }^{206} \mathrm{~Pb}$ concordant ages of 343 concordant to sub-concordant 


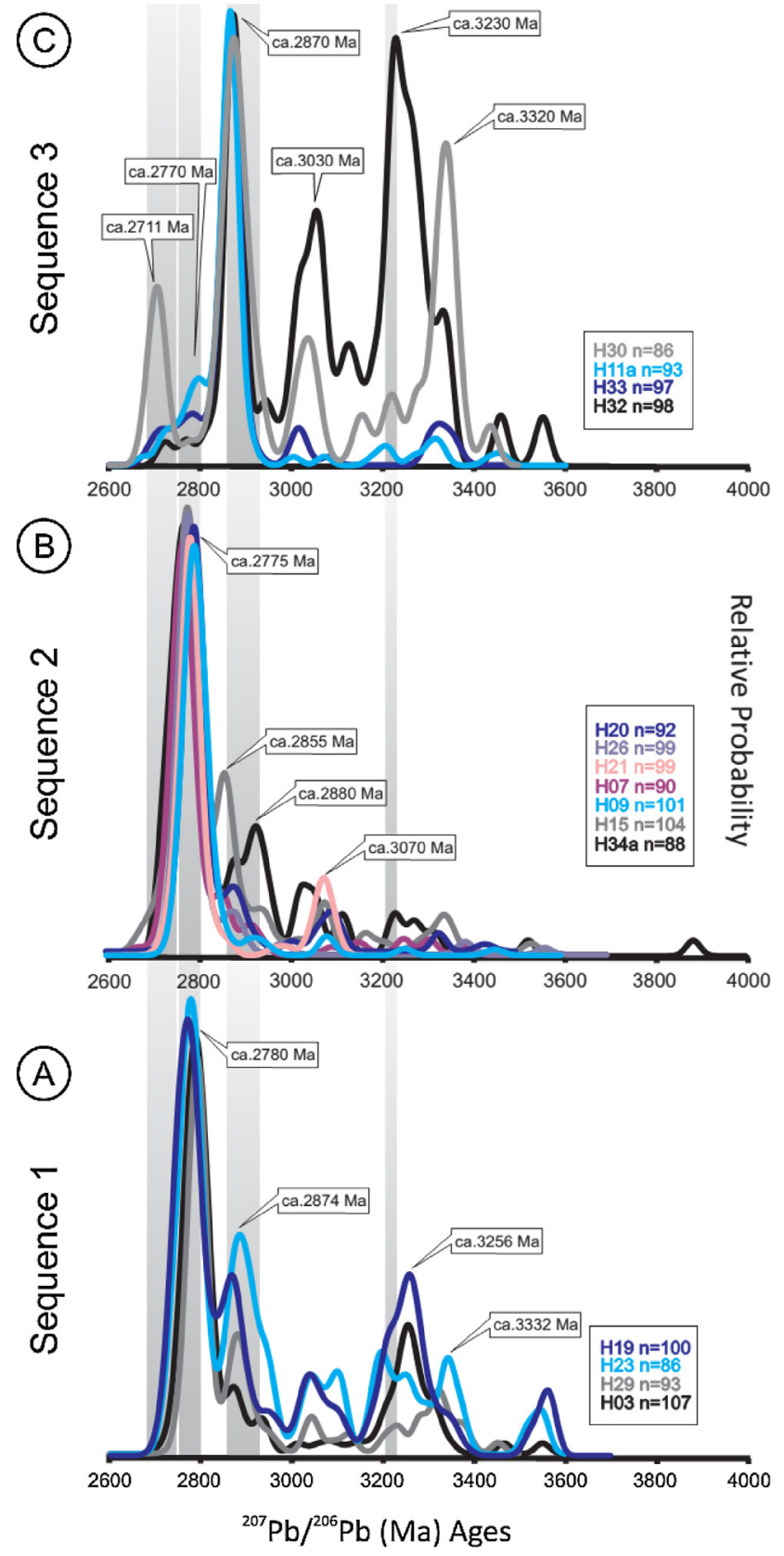

Fig. 7. Probability density diagrams showing ${ }^{207} \mathrm{~Pb} /{ }^{206} \mathrm{~Pb}$ age spectra of the 15 samples of this study divided into Sequences 1, 2 and 3. Number of zircon analyses measured in each sample used to construct the diagrams are indicated. Vertical grey bars indicate the main magmatic events defined by Lana et al. (2013) and redefined by Farina et al. (2015): SB (ca. 3220-3200 Ma); RV I (2920-2850 Ma); RV II (2800-2760 Ma); Mamona event (ca. 2760-2680 Ma).

zircons chosen among the 15 dated samples of the Maquiné Group. $\mathrm{Lu}-\mathrm{Hf}$ isotope analyses were obtained from the same domains, mostly directly on the $\mathrm{U}-\mathrm{Pb}$ spots. In summary, these ratios show an increase from older to younger grains (Fig. 8). The Palaeo to Mesoarchaean (i.e., older than $3000 \mathrm{Ma}$ ) yielded mainly subchondritic $\varepsilon \mathrm{Hf}_{(\mathrm{t})}$, between -4.1 and +3.0 , with variations in $\mathrm{Hf}$ model age $\left(T_{\mathrm{DM}}\right)$ between $4140 \mathrm{Ma}$ and $3220 \mathrm{Ma}$. The Hf isotopic composition of Neoarchaean zircons formed after $3000 \mathrm{Ma}$ (between $3000 \mathrm{Ma}$ and $2700 \mathrm{Ma}$ ), show $\varepsilon \mathrm{Hf}_{(\mathrm{t})}$ values between -7.6 and +3.0. The model ages have a smaller range between 3640 and $3020 \mathrm{Ma}$ (Supplementary data - Table 4). In summary, there is a typical increase in the dispersion of $\varepsilon \mathrm{Hf}_{(\mathrm{t})}$ values,
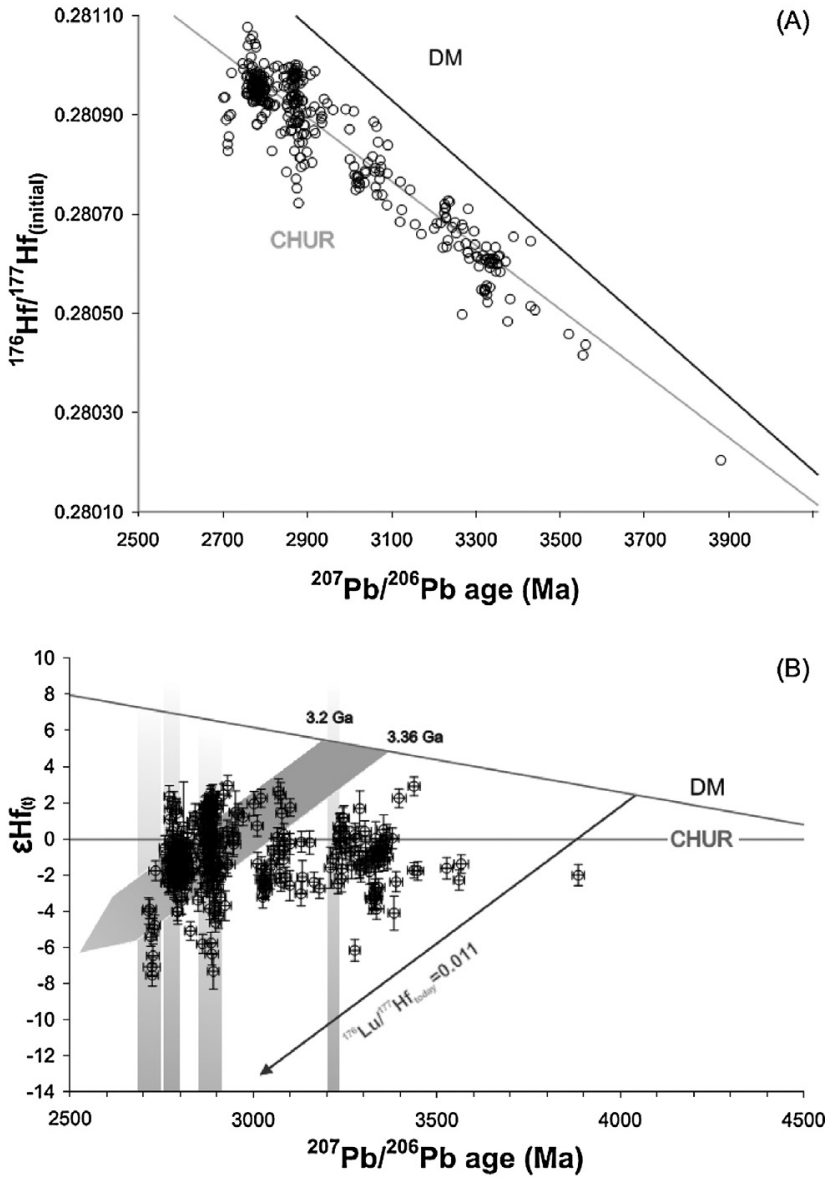

Fig. 8. (A) ${ }^{176} \mathrm{Hf} /{ }^{177} \mathrm{Hf}_{\text {(initial) }}$ versus ${ }^{207} \mathrm{~Pb} /{ }^{206} \mathrm{~Pb}$ age diagram showing all data from the Maquiné Group rocks. (B) $\varepsilon \mathrm{Hf}_{(\mathrm{t})}$ versus ${ }^{207} \mathrm{~Pb} /{ }^{206} \mathrm{~Pb}$ age diagram showing results of detrital zircon of this study. The small arrow marks the evolution of average continental crust with ${ }^{176} \mathrm{Lu} /{ }^{177} \mathrm{Hf}=0.0113$. The big arrow comprises ca. $60 \%$ of all zircons. Vertical grey bars indicate the main magmatic events. For calculation of $\varepsilon \mathrm{Hf}_{(\mathrm{t})}$, CHUR and the depleted mantle evolution trend (DM), the CHUR constants of Bouvier et al. $\left(2008 ;{ }^{176} \mathrm{Hf} /{ }^{177} \mathrm{Hf}=0.282785\right.$ and $\left.{ }^{176} \mathrm{Lu} /{ }^{177} \mathrm{Hf}=0.0336\right)$ and $T_{\mathrm{DM}}$ constants of Blichert-Toft and Puchtel $\left(2010 ;{ }^{176} \mathrm{Hf} /{ }^{177} \mathrm{Hf}=0.283294\right.$ and $\left.{ }^{176} \mathrm{Lu} /{ }^{177} \mathrm{Hf}=0.03933\right)$ were used.

becoming increasingly negative from older to younger zircons (Fig. 8b).

\section{Discussion}

\subsection{Maximum deposition age and the terminal stage of the} greenstone belt evolution

Maximum deposition ages have fundamental implications for stratigraphic correlations, particularly in areas devoid of volcanic units. The maximum age of the Maquine Group is significant because this group separates the two economically important units of the QF, which are the Nova Lima Group (with gold deposits) and the Minas Supergroup (with banded iron formation). The Maquiné Group also marks the waning stages of the greenstone belt evolution and therefore represents a very important stratigraphic marker for greenstone belt correlations in South America. However, constraining the maximum age of deposition of a sedimentary rock is often difficult because measured dates can be affected by uncorrected for common Pb, Pb loss (e.g., Zeh et al., 2008), U/Pb fractionation during analysis, large analytical uncertainties (1-2\% at $2 \sigma$, depending on the method), and inappropriate number of analysis (less than enough to define all of the detrital zircon populations) (e.g., Andersen, 2005; Pullen et al., 2014; Vermeesch, 2004). 

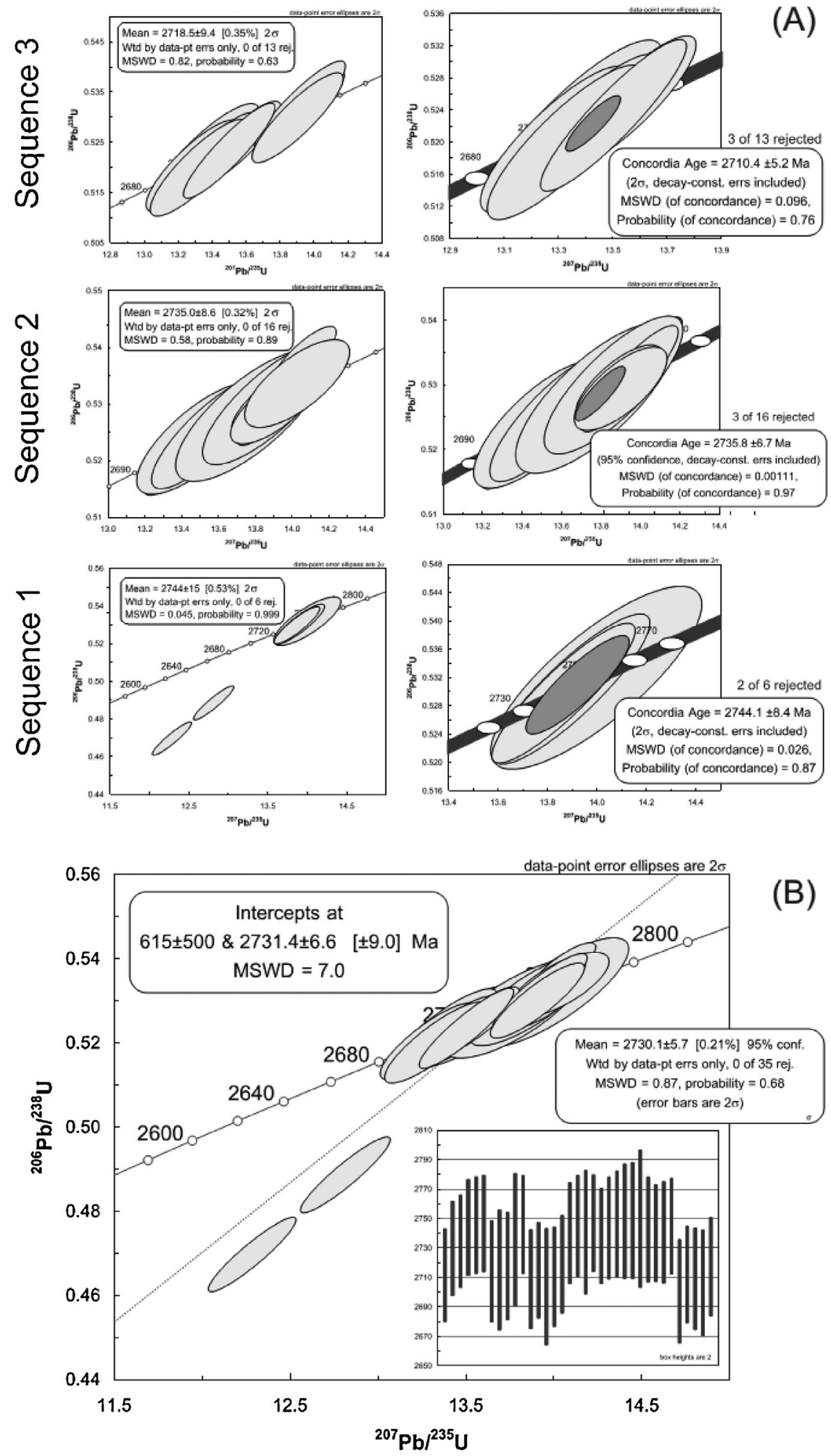

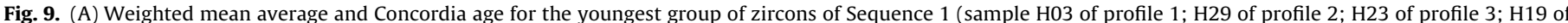

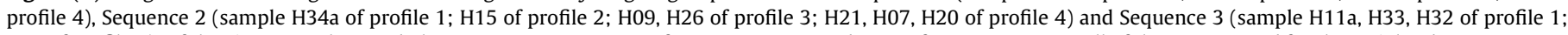

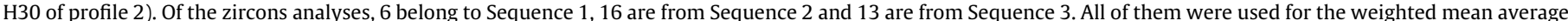

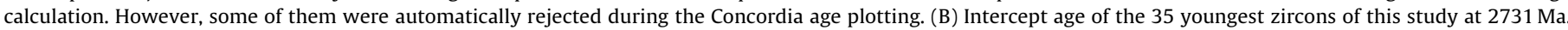
Weighted mean average bars of same analysis are indicated and depict a mean age of ca. $2730 \mathrm{Ma}$.

A detailed study by Dickinson and Gehrels (2009) concluded that the maximum deposition age of a sedimentary sample can be calculated via the weighted mean age (or a peak age probability) of the youngest cluster. These authors also noted that the youngest single grain appears to work in $90 \%$ of the cases. Here we attempted a statistical analysis of the 35 zircons younger than $2750 \mathrm{Ma}$, which is the age of the youngest acid volcanic rock immediately below the basal sediments of the Maquiné Group (Noce et al., 2005). The mean age of the youngest zircons is $2730 \pm 18 \mathrm{Ma}$ which is within uncertainty of the dated volcanic rock. Of the 35 zircons, 6 belong to 


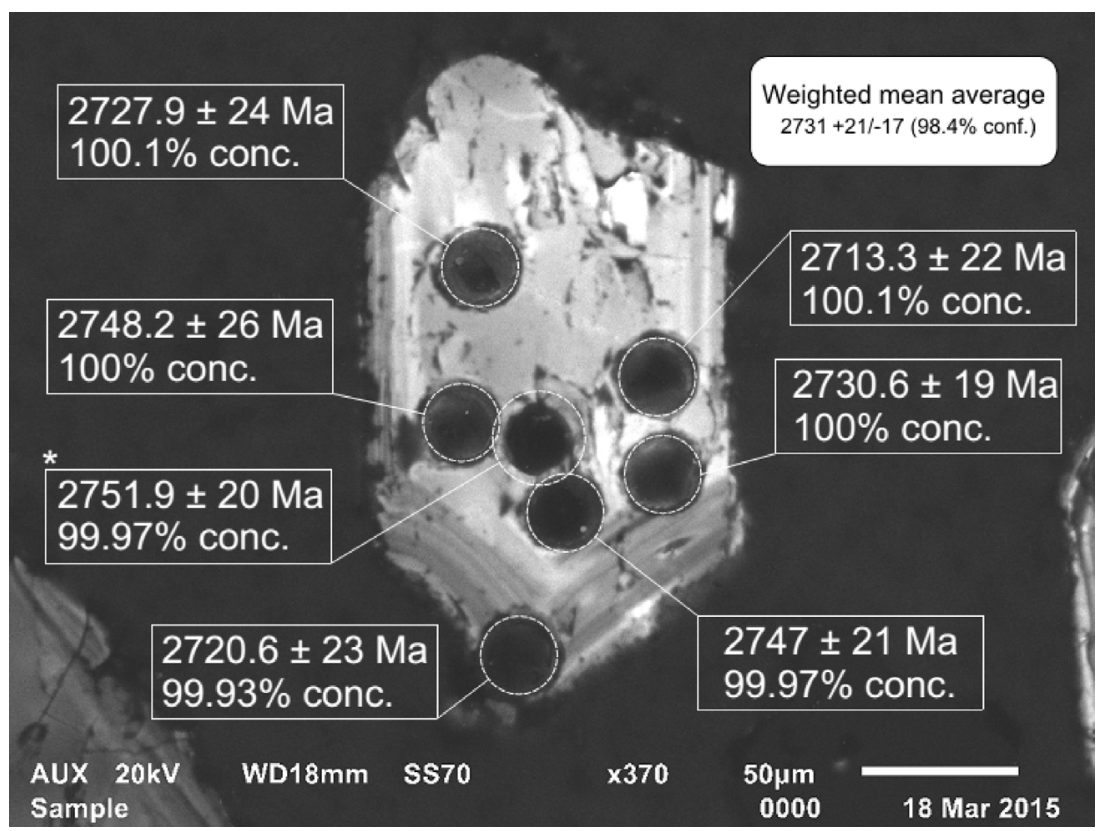

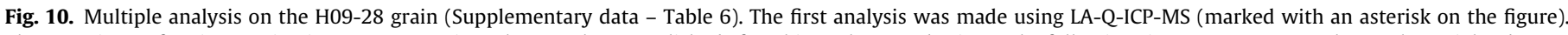

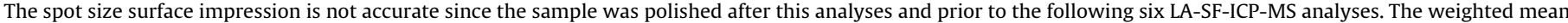
average of those seven analyses is $2731 \mathrm{Ma}$ as indicated in the upper right corner of the figure.

Sequence 1,16 are from Sequence 2 and 13 are from Sequence 3 . The mean ages of Sequence 1, 2 and 3 are $2745 \pm 18 \mathrm{Ma}, 2735 \pm 18 \mathrm{Ma}$ and $2718 \pm 17 \mathrm{Ma}$, respectively (Fig. 9a). The average between the mean age of each sequence is $2733 \pm 18 \mathrm{Ma}$ and the weighted mean average age is $2730 \pm 18 \mathrm{Ma}$ (Fig. 9b). Regarding those averages the maximum deposition age can reasonably be defined as around 2730 Ma.

An attempt to evaluate the maximum depositional age of the sedimentary sequence and the reproducibility of the ages was also made. We acquired multiple analyses in one of the largest, youngest concordant grains (Fig. 10). This zircon grain was first analyzed by LA-Q-ICP-MS, which gave an age similar to the youngest acid volcanic rock dated by Noce et al. (2005). Six further LA-SF-ICP-MS analyses were carried out on the same grain (Supplementary data - Table 6). The individual ages have some variance but a weighted mean average of all 7 analyses yields an age of $2731+21 /-17 \mathrm{Ma}$ (Fig. 10).

In summary, an age of ca. $2730 \mathrm{Ma}$ is proposed as the maximum deposition age for the Maquiné Group. This suggests that the Maquiné Group sediments were deposited at the end of the RV II event. The progressive decrease of the youngest ages towards to the top of the Maquiné Group (Sequence $1=2745 \pm 18 \mathrm{Ma}$; Sequence $2=2735 \pm 18 \mathrm{Ma}$ and Sequence $3=2718 \pm 17 \mathrm{Ma}$ ) suggests sediment accumulation during an evolving volcanic event (discussed later). Several greenstone belts record an age of ca. 2730-2700 Ma, such as those from the Superior Province, in Canada (e.g., Desrochers et al., 1993; Dostal and Mueller, 2013; Kerrich et al., 1998); the Dharwar craton, in India (Manikyamba et al., 2004, 2005); Yilgarn Craton, in Australia (Pidgeon and Wilde, 1990) and Zimbabwe Craton, in Zimbabwe (Bolhar et al., 2003). These ages support the idea of a larger continent composed of these cratons first suggested by Williams et al. (1991) and named Kenorland (or Superia and Sclavia; Bleeker, 2003), which formed at ca. $2700 \mathrm{Ma}$ and broke up at $2500 \mathrm{Ma}$ (Lubnina and Slabunov, 2011). This large continental mass or supercontinent marks the appearance of sedimentary basins in the Late Archaean when the lower topography and higher sea levels of Earth's surface gave way to large areas of exhumed continental crust in the Neoarchaean and greater freeboard (Flament et al., 2008, 2013). This exhumation indicates the termination of the amalgamation of cratons as a result of early sialic microcontinents and the subsequent formation of collisional mountain systems (Rosen, 2011).

\subsection{Evolution of the Maquiné basin}

The Maquiné Group is a set of sedimentary sequences marking the transition from a flysch to molasse basin (Dorr, 1969). This transition is characterized by pelitic to impure sandstones with a clay matrix, giving way to more conglomeratic sediments towards the top of the group. The influx of extrabasinal detritus began earlier in the history of the belt when several 2780-2750 Ma volcanoclastic layers were deposited on top of turbidites of the Nova Lima Group (Noce et al., 2005). These turbidites and volcanic rocks mark the beginning of an important change in sedimentation in the Rio das Velhas Greenstone Belt, where relatively calm marine sedimentation was replaced by a syn-orogenic voluminous sediment supply, coming particularly from the RV II volcanic arc. Immediately above these volcanoclastic layers we documented three main stages of deposition in the Maquiné Group (Fig. 4), which are separated in our profiles as Sequence 1, 2 and 3. Sequence 1 is marked by deposition of pelagic phyllites of the Nova Lima Group, coarsening upwards into sericitic quartzite and quartzose phyllite to form the Palmital Formation. This gradational contact suggests that the Palmital Formation could be part of the flysch deposit that characterizes much of the Nova Lima Group.

As with the 2780-2750 Ma volcanoclastic sequences of the Nova Lima Group, the geochronologic data for samples in Sequence 1 (H3, H29, H23 and H19) testify to erosion and accumulation of synorogenic detritus in addition to minor erosion of the pre-existing continental crust. These samples are marked by one single age distribution with two major peaks in the intervals 2760-2800 Ma and 2850-2900 Ma, and a secondary peak between 3200 and $3355 \mathrm{Ma}$. The first peak relates to the syn-orogenic detritus that started accumulating at the top of the Nova Lima Group (RV II). The second peak clearly indicates that the underlying crust (RV I - 2930-2900 Ma) was being exhumed and eroded during orogeny. Although, the magmatic record suggests a narrow 30 Ma period of magmatism for the RV I (Lana et al., 2013), our detrital zircon data seem to 


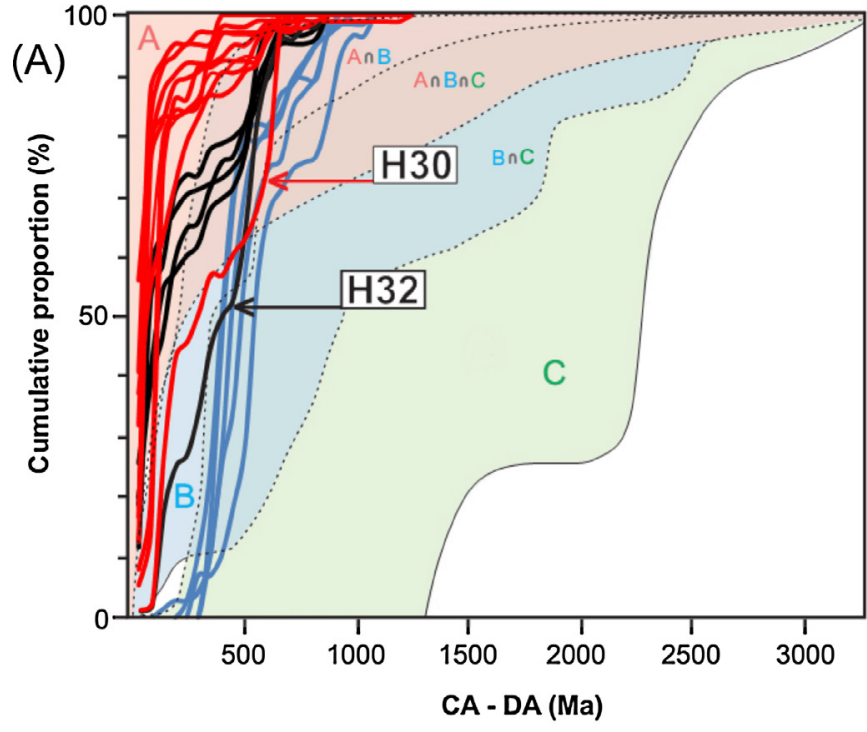

— Casa Forte Fm. — Palmital Fm. — Cercadinho Fm.

(B)

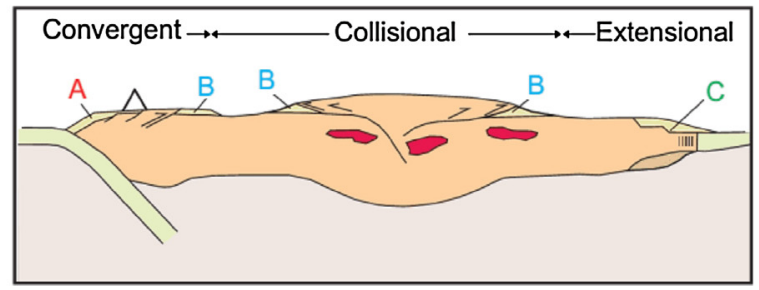

Fig. 11. (A) Summary plot of variation of the difference between the measured crystallization age for a detrital zircon grain and the depositional age of the succession in which it occurs based on cumulative proportion curves of Cawood et al. (2012) for the 15 samples of this study (black curves - Palmital Formation; red curves Casa Forte Formation) and 5 samples of a passive margin sedimentary rock (blue curves) for comparison; (B) Schematic cross section of convergent - A, collisional $B$ and extensional - $C$ plate boundaries associated with supercontinent cycle showing simplified basin settings for accumulation of detrital zircons (from Cawood et al. 2012, 2013). (For interpretation of the references to colour in this figure legend, the reader is referred to the web version of this article.)

indicate an extended period from 2930 to $2870 \mathrm{Ma}$. Likewise, the population of zircons with ages around $3200 \mathrm{Ma}$ is consistent with the Santa Bárbara event, but older populations suggest the presence of other Mesoarchaean crustal segments not yet detected in the São Francisco Craton (discussed later).

Sequence 2 records a substantial change in the environment and source from those that produced Sequence 1 . Here, the basin was filled by poorly sorted clastic sandstones with local monomict conglomerates at the base, and polymict conglomerates in the central part of the sequence. The polymict conglomerate records a wide-range clasts derived from erosion of the Nova Lima Group and Palmital Formation (see also Dorr, 1969). This includes fragments of pelites, mafic rocks and banded iron formation, suggesting exhumation of the Nova Lima flysch basin during deposition of Sequence 2. According to Baltazar and Zucchetti (2007), the association of clast-supported conglomerates with cross-bedded sandstones may indicate deposition within an alluvial-fluvial fan. All of the seven samples collected from Sequence 2 ( 4 conglomerates and 3 meta-arenites) have one dominant age peak at ca. $2780 \mathrm{Ma}$ and other less significant peaks at ca. $2870 \mathrm{Ma}, 3070 \mathrm{Ma}, 3200 \mathrm{Ma}$ and $3350 \mathrm{Ma}$ (Fig. 7b). The large population of 2780-2800 Ma zircons and the large volumes of conglomerates indicate erosion of the arc in its peak of magmatic activity and substantially less erosion of the older crust. The thick coarsening-upward trend recorded from
Sequence 1 to Sequence 2 also suggests a tectonically active, possibly near-shore depositional environment with a magmatic source from the west.

In contrast, Sequence 3 marks a sudden loss of energy with the deposition of shales. Although Sequence 3 samples contain appreciable amounts of zircon aged at ca. $2780 \mathrm{Ma}$, samples belonging to this sequence have significant and even main peaks (in the case of sample H32) in the range of 3200-3255 Ma, indicating a change in source to much older crustal rocks. We suggest that detrital zircon spectra of Sequence 3 reflects a depletion of RV II (2760-2800 Ma) rocks from the source and exhumation of the older crustal rocks such as those formed during the RV I and Santa Bárbara events.

While Sequences 1 and 2 sampled mostly zircons from the RV II crust, Sequence 3 has a distinctive flame-type pattern similar in many ways to rift-related sandstones and conglomerates of the Minas Supergroup. However, a critical difference between the Maquiné and Minas sediments is that the latter are mainly marked by younger zircons ranging in age from 2600 to $2700 \mathrm{Ma}$ (Machado et al., 1996; Hartmann et al., 2006; Cassino, 2014; Koglin et al., 2014), clearly consistent with field observations that suggest that deposition of the base of the Minas Supergroup occurred after 2750-2600 Ma potassic magmatism (Romano et al., 2013; Lana et al., 2013). Thus, the accumulation of the Maquiné basin occurred during a transitional period in the magmatic evolution of the craton, when arc related juvenile TTG magmatism suddenly changed to a period of massive crustal melting and emplacement of calc-alkaline potassic granitoids (Romano et al., 2013; Farina et al., 2015).

The distribution of age peaks within Sequences 1 and 2 are identical to unimodal detrital zircon populations observed in other convergent basins (Cawood et al., 2012). Fig. 11 shows the cumulative distribution of zircon ages in each sample versus the difference between the crystallization age of the grains and the estimated deposition age of the unit to which the sample belongs. This parameter is directly related to the tectonic framework of the basin (Cawood et al., 2012). Five samples belonging to the Cercadinho Formation of the Minas Supergroup (Mendes et al., 2014; Cassino, 2014) are also shown for comparison. With the exception of sample H30, samples of the Casa Forte Formation have patterns consistent with a convergent margin setting. This is because the predominant peak of zircon ages is very close to the age of deposition and therefore suggests fast erosion of the arc and thus deposition within a convergent environment (Fig. 11b). The shift observed for the Palmital Formation samples suggest that deposition was still in the early stages of subduction, with some contribution of deep marine deposits. Samples H32 and H30 (Fig. 11a) are shifted further to the right closer to the collisional field. These samples correspond to Sequence 3 and reflect basin closure, meaning that the Maquiné basin was in the final stages of accumulation of sediments. Samples of the Cercadinho Formation, interpreted as a passive margin basin (Dorr, 1969; Renger et al., 1995; Alkmim and Martins-Neto, 2012), have detrital zircon age patterns consistent with a passive margin environment (see Cawood et al., 2012, 2013). The absence of younger magmatic events, the advance of erosion and peneplanation of source areas depleted the contribution of younger sources and exposed older sources.

\subsection{Archaean syn-orogenic convergent basins}

The transition from the Nova Lima to the Maquiné Group compares well with the stratigraphy of the Fig Tree Group in the Barberton Greentone Belt, South Africa. The Fig Tree Group and the Nova Lima/Maquiné transition are marked by deposition of syn-orogenic, terriginous/volcanoclastic rocks on top of chemical marine sediments and mafic/ultramafic greenstone belt sequences (e.g., Eriksson, 1980; Lowe and Nocita, 1999; Baltazar and Zucchetti, 
Convergent Stage
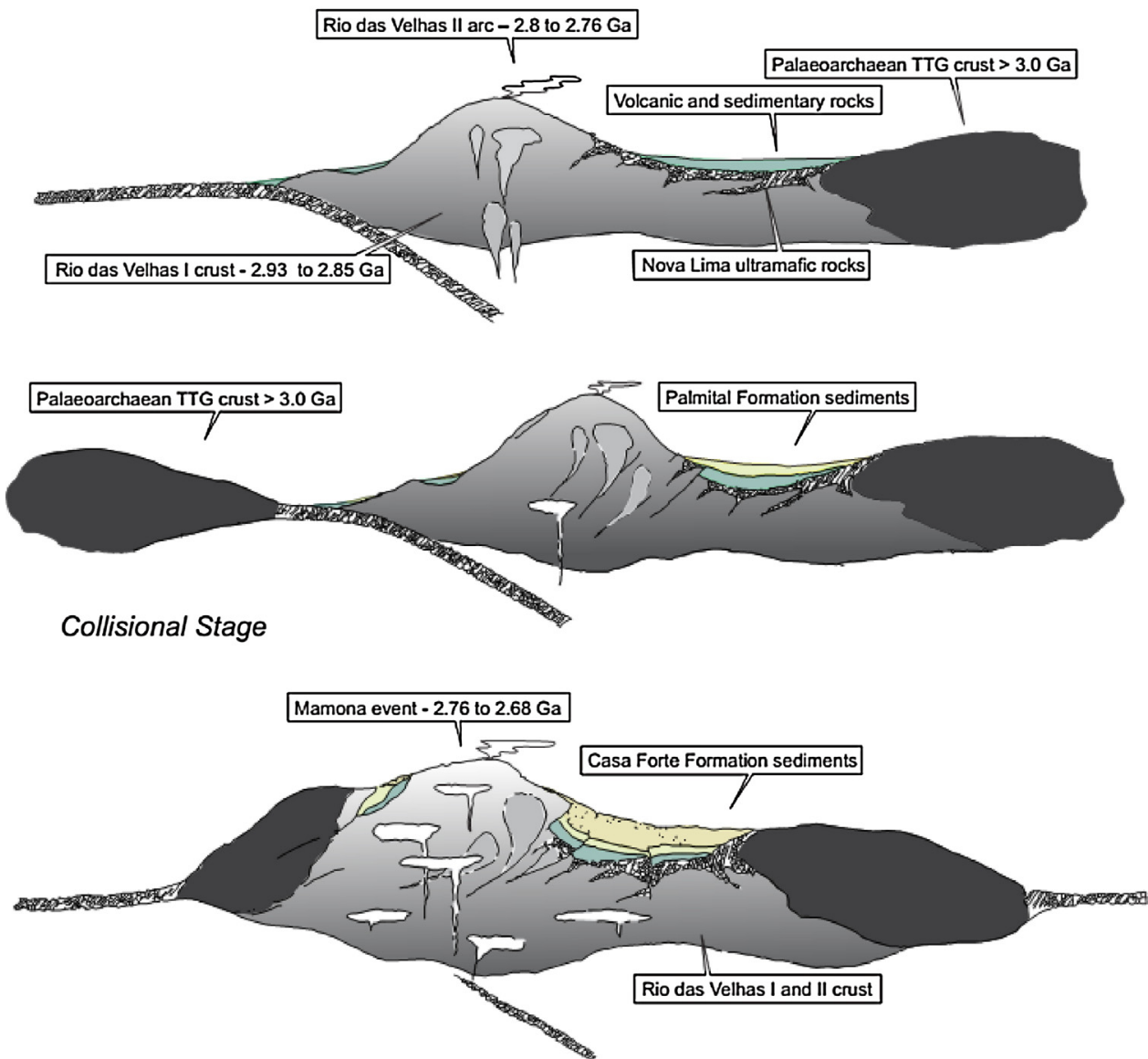

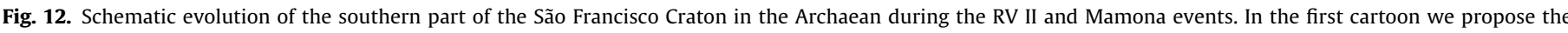

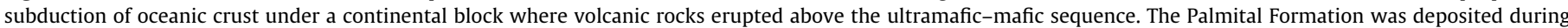

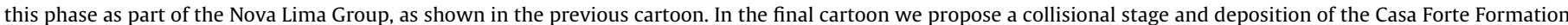

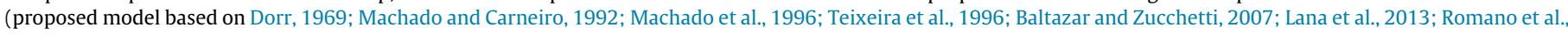
2013; Farina et al., 2015; this study).

2007; van Kranendonk et al., 2009). Such volcaniclastic deposits consist of pyroclastic/reworked volcanic detritus, covered by proximal terrigenous deposits that coarsen upward from predominantly siltstone and fine-grained sandstone at the base to pebble and cobble conglomerate at the top. For the Fig Tree Group, previous studies have proposed deposition in a back-arc/convergent environment based on the nature of the sediments and regional constraints (Eriksson, 1980; Lowe and Nocita, 1999; Kohler and Anhaeusser, 2002). The timing of the volcanoclastic deposition in the Fig Tree basin overlaps with a period of tectonic convergence, magmatism and collision of two main terranes of the greenstone belt at ca. 3200 Ma (De Wit et al., 1992; Lowe, 1994; Kröner et al., 1996; Kamo and Davis, 1994; Lana et al., 2010b, 2011; Schoene et al., 2008).

Evidence of syn-orogenic deposition of the Nova Lima and Maquiné Groups is indicated by: (1) the overlap between the ages of volcanoclastic layers in the greenstone belt rocks and TTG magmatism (RV II) in the basement (Noce et al., 2005), (2) the nearly unimodal peak in the zircon age populations of Sequences 1 and 2; and (3) the Lu-Hf isotopic signature of the RV II zircons (discussed below).

Fig. 12 summarizes the results of regional constraints defining the RV II granitoids as a magmatic arc (Machado and Carneiro, 1992; Machado et al., 1996; Teixeira et al., 1996; Lana et al., 2013; Romano et al., 2013; Farina et al., 2015), and the Nova Lima and Maquiné sediments in a convergent tectonic regime (Dorr, 1969; Baltazar and Zucchetti, 2007; this study). Machado and Carneiro
(1992) and Machado et al. (1992) were the first to recognize coeval magmatism in the basement and extrusion of felsic volcanic rocks in the greenstone belt. According to Machado et al. (1992) the development of the greenstone belt was coeval with the granitoid magmatism at $2770 \mathrm{Ma}$. The concomitant magmatism and volcanism at 2770-2800 Ma was later interpreted as part of magmatic arc (RV II) along the margins of a $>2900$ Ma crustal block (Lana et al., 2013). Thus the distinctive uni-modal, detrial zircon age pattern recorded in Sequences 1 and 2 of the Maquiné Group is consistent with previous interpretation of an accretionary system during the RV II. We propose that the Maquiné Group was deposited in a foredeep or foreland basin developed partly on the Rio das Velhas Greenstone Belt and partly on the TTG crust. In such an environment the upward coarsening recorded by Sequences 1 and 2 occurred as a direct response to progressive uplift of the source. This syn-orogenic deposition with rapid exhumation and erosion of the source most likely provided, within a few million years, the large volumes of RV II zircons for Sequences 1 and 2 (Fig. 12).

The change in depositional style from fine-grained clay and siltstones at the top of the Nova Lima to quartzites and conglomerates of the Maquiné Group, together with the unimodal detrital zircon pattern of Sequences 1 and 2 are consistent with the continuous growth of the RV II magmatic arc and possibly exhumation of the greenstone belt rocks within a convergent environment (Fig. 12). Such a change must have involved exhumation of nearly all of the crystalline TTG crust, including the Santa Bárbara and Rio das 

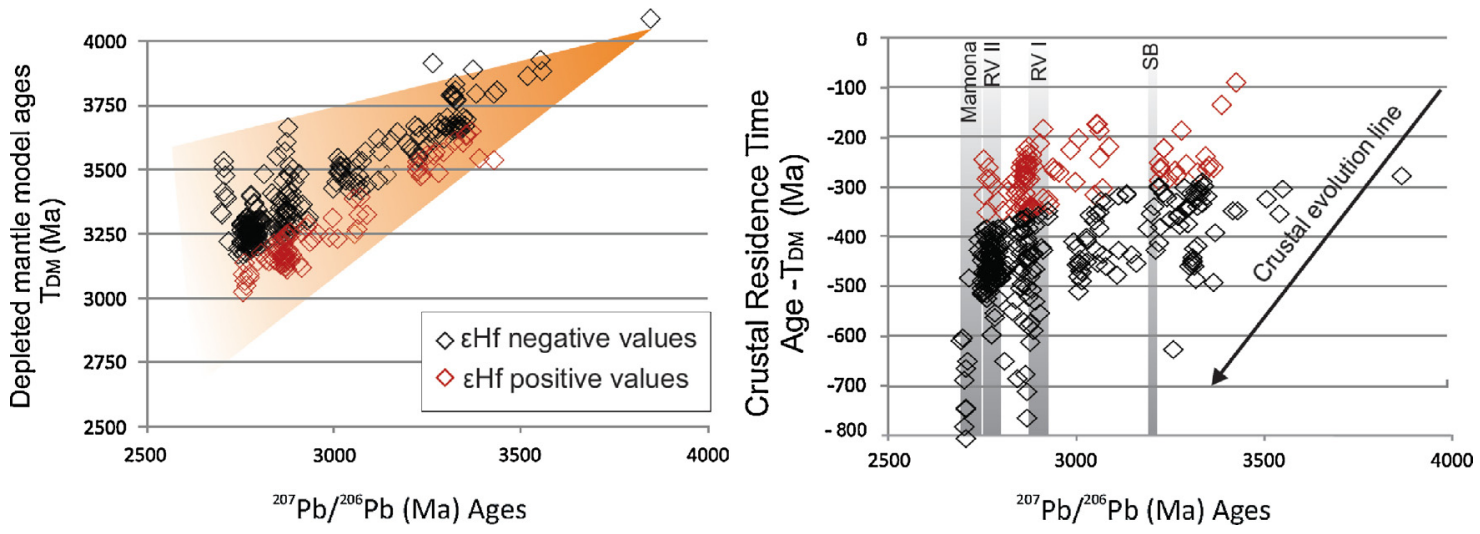

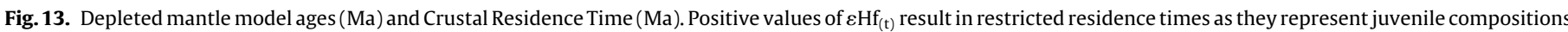

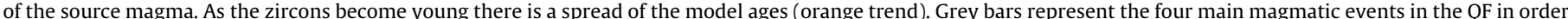
of decreasing age: SB, RV I, RV II and Mamona. (For interpretation of the references to colour in this figure legend, the reader is referred to the web version of this article.)

Vellhas I and II TTG rocks. Given the maximum depositional age of the Maquiné Group is ca. 2730 Ma, it is likely that the exhumation coincided with potassic magmatism and thickening of the crust in a collisional event.

\subsection{Implications for crustal evolution}

The Maquine Group is the last pre-Minas Supergroup clastic sequence (Fig. 2) and, as discussed above, it contains zircons derived from large parts of the crystalline basement of the Southern São Francisco Craton. Thus, the study of detrital zircons of the Maquiné Group becomes the key to understanding the Palaeoarchaean history of the southern portion of the São Francisco Craton, since these rocks preserve undamaged zircons very effectively.

Apart from regional constraints and geochemical data published recently (Romano et al., 2013; Lana et al., 2013; Farina et al., 2015) there has been no information about the isotopic evolution of the RV I and RV II rocks. The detrital zircons belonging to the interval 2930-2870 Ma and 2800-2770 Ma, record positive and negative $\varepsilon \mathrm{Hf}_{(\mathrm{t})}$ values. Positive values for $\varepsilon \mathrm{Hf}_{(\mathrm{t})}$, reach up to +3 and support the idea of juvenile magmatic additions during both RV I and RV II. However, since the model ages $\left(T_{\mathrm{DM}}\right)$ for these zircons are in the range of $2900-3100 \mathrm{Ma}$, the positive and negative $\varepsilon \mathrm{Hf}_{(\mathrm{t})}$ values require a mixture of juvenile and reworked crust (Fig. 8 ). Therefore, the two main magma producing events in the Southern São Francisco Craton (RV I and RV II) seem to have been developed around older continental crust. A close inspection of the crustal residence time for those zircons (Fig. 13) indicates that subchondritic zircons corresponding to RV I and II events have substantially longer residence time than those of older magmatic events such as the Santa Bárbara event, suggesting that crustal reworking began in the Mesoarchaean and increased towards the Neoarchaean.

Several detrital zircon ages of 3500-3600 Ma and one of ca. $3900 \mathrm{Ma}$ (see also Hartmann et al., 2006) indicate that the crust of the SSFC may be as old as that within the Kaapvaal and Zimbabwe Cratons. The $T_{\mathrm{DM}}{ }^{\mathrm{Hf}}$ initial values obtained from the Maquiné zircons are similar to those calculated for felsic rocks of the Barberton Greenstone Belt (Amelin et al., 2000; $T_{\mathrm{DM}}{ }^{\mathrm{Hf}}=3610-3750 \mathrm{Ma}$ ), to Sm-Nd isotope data for basic and ultrabasic rocks from the Kaapvaal Craton (Wilson and Carlson, 1989) and for felsic rocks of the Tokwe segment of the Zimbabwe Craton $\left(T_{\mathrm{DM}}{ }^{\mathrm{Nd}}=3550-3670 \mathrm{Ma}\right.$, data from Moorbath et al., 1986; Taylor et al., 1991). In South America, fragments of older crust have been identified in sandstones of the SSFC around 3500 and $3800 \mathrm{Ma}$ (e.g., Machado et al., 1996; Hartmann et al., 2006). The oldest zircon dated in this study at $3882 \pm 30 \mathrm{Ma}(2 \sigma)$ reinforces the possibility of Palaeoarchaean crust in the SSFC. Moreover, its older model age $\left(T_{\mathrm{DM}} \mathrm{Hf}^{\mathrm{H}}-4140 \mathrm{Ma}\right)$ associated with its negative $\varepsilon \mathrm{Hf}_{(\mathrm{t})}$ value $(-2.0)$ suggests an even older reworked crust in this region. Considering the significant amount of data in this study ( $\sim 1500$ dated zircons), which probably covered the whole zircon spectrum in the Maquiné Group, it is reasonable to suggest that either the older crustal segments in the area have been efficiently recycled by younger events or they were not initially present in large volumes. This suggestion is also supported by the worldwide trend of continental crustal growth being more voluminous in the Mesoarchaean and Neoarchaean than in older times (e.g., Nutman, 2001; Dhuime et al., 2012).

\section{Conclusions}

(1) Cumulative proportion curves indicate that the Maquiné Group is a convergent basin with the following characteristics: (1) a clear ageing of the source as the basin evolves, (2) drastic changes in clast composition up section, (3) strong upward coarsening as a consequence of fast exhumation of the source, (4) youngest detrital zircon ages very close to the timing of deposition (within $20 \mathrm{Ma}$ ), and (5) strong uni-modal detrital zircon age spectra for most parts of the sequence.

(2) The Maquiné basin is an ideal natural laboratory to understand the long-lived evolution of the Archaean continental crust in the southern São Francisco Craton. U-Pb and Lu-Hf isotope systematics of zircons from the Maquiné Group provide evidence of the three main periods of magmatism and a protracted evolution of crustal development in the craton. Zircons older than $3000 \mathrm{Ma}$ yield mainly subchondritic $\varepsilon \mathrm{Hf}_{(\mathrm{t})}$ values between -4.1 and +3.0 and model ages $\left(T_{\mathrm{DM}}\right)$ between 4140 and $3220 \mathrm{Ma}$. Neoarchaean zircons formed between 3000 and 2700 Ma yield a larger range of $\varepsilon \mathrm{Hf}_{(\mathrm{t})}$ values $(-7.6$ to +3.0$)$ and smaller range of $T_{\mathrm{DM}}$ ages (between 3640 and $3020 \mathrm{Ma}$ ). Thus, the dispersion of $\varepsilon \mathrm{Hf}_{(\mathrm{t})}$ values increases, becoming more negative the younger the zircons are. Positive values for $\varepsilon \mathrm{Hf}_{(\mathrm{t})}$, reaching up to +3.0 support the idea that magmas were partially juvenile and incorporated a significant amount of reworked material. The values corresponding to RV I and II events are substantially more negative than older magmatic events such as the Santa Bárbara, suggesting that crustal reworking initiated in the Palaeoarchaean and increased towards the Neoarchaean. The observed pattern of $\varepsilon \mathrm{Hf}_{(\mathrm{t})}$ versus time supports the reworking process of continental crust models in combination with crust-mantle.

(3) Our U-Pb-Hf dataset supports the interpretation of a long-lived evolution for the southern São Francisco Craton through a succession of magmatic arcs in the Archaean. 


\section{Acknowledgments}

This project was sponsored by Fapemig (APQ03943); CNPQ (402852/2012-5; 401334/2012-0; 302633/2011-1); Fapemig-Vale (CRA RDP-0067-10; 00063/10); FINEP CT-INFRA.

\section{Appendix A. Supplementary data}

Supplementary data associated with this article can be found, in the online version, at http://dx.doi.org/10.1016/j.precamres.2015. 12.015 .

\section{References}

Alkmim, F.F., Marshak, S., 1998. The Transamazonian orogeny in the Quadrilátero Ferrífero, Minas Gerais Brazil: Paleoproterozoic Collision and Collapse in the Souhtern São Francisco Craton region. Precambrian Res. 90, 29-58.

Alkmim, F.F., Martins-Neto, M.A., 2012. Proterozoic first-order sedimentary sequences of the São Francisco Craton, eastern Brazil. Mar. Pet. Geol. 33, $127-139$.

Amelin, Y., Lee, D.C., Halliday, A.N., 2000. Early-middle Archaean crustal evolution deduced from $\mathrm{Lu}-\mathrm{Hf}$ and $\mathrm{U}-\mathrm{Pb}$ isotopic studies of single zircon grains. Geochim. Cosmochim. Acta 64, 4205-4225

Andersen, T., 2005. Detrital zircons as tracers of sedimentary provenance: limiting conditions from statistics and numerical simulation. Chem. Geol. 216, 249-270.

Anhaeusser, C.R., 2014. Archaean greenstone belts and associated granitic rocks - a review. J. Afr. Earth Sci. 100, 684-732.

Babinski, M., Chemale Jr., F., Van Schmus, W.R., 1995. The $\mathrm{Pb} / \mathrm{Pb}$ age of the Minas Supergoup carbonate rocks, Quadrilátero Ferrífero Brazil. Precambrian Res. 72. 235-245.

Baltazar, O.F., Zucchetti, M., 2007. Lithofacies associations and structural evolution of the Archean Rio das Velhas greenstone belt, Quadrilátero Ferrífero Brazil: a review of the setting of gold deposits. Ore Geol. Rev. 32, 1-2.

Black, L.P., Gulson, B.L., 1978. The age of the Mud Tank carbonatite, Strangways Range Northern Territory. BMR J. Aust. Geol. Geophys. 3, 227-232.

Black, L.P., Kamo, S.L., Allen, C.M., Aleinikoff, J.N., Davis, D.W., Korsch, R.J., Foudoulis, C., 2003. TEMORA 1 a new zircon standard for phanerozoic U-Pb geochronology. Chem. Geol. 200, 155-170.

Bleeker, W., 2003. The Late Archean record: a puzzle in ca. 35 pieces. Lithos 71, 99-134.

Blichert-Toft, J., Puchtel, I.S., 2010. Depleted mantle sources through time: evidence from Lu-Hf and Sm-Nd isotope systematics of Archean komatiites. Earth Planet. Sci. Lett. 297, 598-606.

Bolhar, R., Woodhead, J.D., Hergt, J.M., 2003. Continental setting inferred for emplacement of the 2.9-2.7 Ga Belingwe Greenstone Belt Zimbabwe. Geol. Soc. Am. 31, 295-298.

Bouvier, A., Vervoort, J.D., Patchett, P.J., 2008. The Lu-Hf and Sm-Nd isotopic composition of CHUR: constraints from unequilibrated chondrites and implications for the bulk composition of terrestrial planets. Earth Planet. Sci. Lett. 273, 48-57.

Buick, I.S., Lana, C., Gregory, C., 2011. A LA-ICP-MS and SHRIMP U/Pb age constraint on the timing of REE mineralisation associated with Bushveld granites. South Afr. J. Geol. 144, 1-14.

Cassino, L.F., 44 p. 2014. Distribuiç̃ão de idades U-Pb de zircões detríticos dos Supergrupos Rio das Velhas e Minas na Serra de Ouro Preto, Quadrilátero Ferrífero, MG - implicações para a evolução sedimentar e tectônica. Unpublished Monography.

Cawood, P.A., Nemchin, A.A., Leverenz, A., Saeed, A., Balance, P.F., 2007.U/Pb dating of detrital zircons: implications for the provenance record of Gondwana margins. Geol. Soc. Am. Bull. 111, 1107-1119.

Cawood, P.A., Hawkesworth, C.J., Dhuime, B., 2012. Detrital zircon record and tectonic setting. Geology 40 (10), 875-878.

Cawood, P.A., Hawkesworth, C.J., Dhuime, B., 2013. The continental record and the generation of continental crust. Geol. Soc. Am. Bull. 125 (1-2), 14-32.

Condie, K.C., Belousova, E., Griffin, W.L., Sircombe, K.N., 2009. Granitoid events in space and time: constraints from igneous and detrital zircon age spectra. Gondwana Res. 15, 228-242.

Davis, D.W., 2002. U-Pb geochronology of Archean metasedimentary rocks in the Pontiac and Abitibi subprovinces Quebec, constraints on timing, provenance and regional tectonics. Precambrian Res. 115, 97-117.

Desrochers, J.-P., Hubert, C., Ludden, J.N., Pilote, P., 1993. Accretion of Archean oceanic plateau fragments in the Abitibi greenstone belt Canada. Geology 21, 452-454.

De Wit, M.J., Roering, C., Hart, R.J., Armstrong, R.A., De Ronde, C.E.J., Green, R.W.E., Tredoux, M., Peberdy, E., Hart, R.A., 1992. Formation of an Archaean continent. Nature 357, 553-562.

Dhuime, B., Hawkesworth, C.J., Cawood, P.A., Storey, C.D., 2012. A change in the geodynamics of continental growth 3 billion years ago. Science 335, 1334-1336, http://dx.doi.org/10.1126/science.1216066.

Dickinson, W.R., Gehrels, G.E., 2009. Use of U-Pb ages of detrital zircons to infer maximum depositional ages of strata: a test against a Colorado Plateau Mesozoic database. Earth Planet. Sci. Lett. 288, 115-125.
Dickinson, W.R., Suczek, C.A., 1979. Plate tectonics and sandstone compositions. Am. Assoc. Pet. Geol. Bull. 63, 2164-2182.

Dorr II, J.V.N., 1969. Physiographic, Stratigraphic and Structural Development of the Quadrilátero Ferrífero, Minas Gerais, Brazil. USGS/DNPM, Washington Prof. Paper 641-A, pp. 110 p.

Dostal, J., Mueller, W.U., 2013. Deciphering an Archean mantle plume: Abitibi greenstone belt Canada. Gondwana Res. 23, 493-505.

Eriksson, K.A., 1980. Transitional sedimentation styles in the Moodies and Fig Tree Groups, Barberton Mountain Land South Africa: evidence favouring an Archean continental margin. Precambrian Res. 12, 141-160.

Farina, F., Albert, C., Lana, C., 2015. The Neoarchean transition between mediumand high-K granitoids: clues from the Southern São Francisco Craton (Brazil). Precambrian Res. 266, 375-394.

Fedo, C.M., Sircombe, K.N., Rainbird, R.H., 2003. Detrtial zircon analysis of the sedimentary record. In: Hanchar, J.M., Hoskin, P.W.O. (Eds.), Zircon, Reviews in Mineralogy and Geochemistry, 53, pp. 277-303.

Flament, N., Coltice, N., Rey, P.F., 2008. A case for late-Archaean continental emergence from thermal evolution models and hypsometry. Earth Planet. Sci. Lett. 275, 326-336.

Flament, N., Coltice, N., Rey, P.F., 2013. The evolution of the ${ }^{87} \mathrm{Sr} /{ }^{86} \mathrm{Sr}$ of marine carbonates does not constrain continental growth. Precambrian Res. 229, $177-188$.

Gair, J.E., 1962. Geology and ore deposit of the Nova Lima and Rio Acima quadrangles, Minas Gerais, Brazil. Washington, USGS/DNPM. Professional Paper 341(A), 67 p.

Garzanti, E., Doglioni, C., Vezzoli, G., Andò, S., 2007. Orogenic belts and orogenic sediment provenance. J. Geol. 115, 315-334, http://dx.doi.org/10.1086/512755.

Gehrels, G., 2011. Detrital zircon U-Pb geochronology: current methods and new opportunities. In: Busby, C., Azor, A. (Eds.), Tectonics of Sedimentary Basins. Blackwell Publishing Ltd., UK, pp. 45-62, http://dx.doi.org/10.1002/ 9781444347166.ch2.

Gehrels, G., 2014. Detrital zircon U-Pb geochronology applied to tectonics. Annu. Rev. Earth Planet. Sci. 42, 127-149.

Gerdes, A., Zeh, A., 2006. Combined U-Pb and Hf isotope LA-(MC-)ICP-MS analyses of detrital zircons: comparison with SHRIMP and new constraints for the provenance and age of an Armorican metasediment in central Germany. Earth Planet. Sci. Lett. 249, 47-61.

Gerdes, A., Zeh, A., 2009. Zircon formation versus zircon alteration - new insights from combined U-Pb and Lu-Hf in situ LA-ICP-MS analyses, and consequences for the interpretation of Archean zircon from the Limpopo Belt. Chem. Geol. 261, $230-243$.

Hartmann, L.A., Santos, J.O.S., 2004. Predominance of high Th/U, magmatic zircon in Brazilian shield sandstones. Geology 32, 73-76.

Hartmann, L.A., Endo, I., Suita, M.T.F., Santos, J.O.S., Frantz, J.C., Carneiro, M.A. Naughton, N.J., Barley, M.E., 2006. Provenance and age delimitation of Quadrilátero Ferrífero sandstones based on zircon U-Pb isotopes. J. South Am. Earth Sci. 20, 273-285.

Hawkesworth, C., Cawood, P., Kemp, T., Storey, C., Dhuime, B., 2009. A matter of preservation. Science 323, 49-50, http://dx.doi.org/10.1126/science.1168549.

Hawkesworth, C., Dhuime, B., Pietranik, A., Cawood, P., Kemp, T., Storey, C. 2010. The generation and evolution of the continental crust. J. Geol. Soc. 167, 229-248.

Jackson, S.E., Pearson, N.J., Griffin, W.L., Belousova, E.A., 2004. The application of laser ablation-inductively coupled plasma-mass spectrometry to in situ U-Pb zircon geochronology. Chem. Geol. 211, 47-69.

Kamo, S.L., Davis, D.W., 1994. Reassessment of Archean crustal development in the Barberton Mountain Land South Africa, based on U-Pb dating. Tectonics 13 , 167-192.

Kaur, P., Zeh, A., Chaudhri, N., Gerdes, A., Okrusch, M., 2013. Nature of magmatism and sedimentation at a Columbia active margin: insights from combined $\mathrm{U}-\mathrm{Pb}$ and $\mathrm{Lu}-\mathrm{Hf}$ isotope data of detrital zircons from NW-India. Gondwana Res. 23, 1040-1053.

Kerrich, R., Wyman, D., Fan, J., Bleeker, W., 1998. Boninite series: low-Ti tholeiite associations from the $2.7 \mathrm{Ga}$ Abitibi greenstone belt. Earth Planet. Sci. Lett. 164, 303-316.

Koglin, N., Zeh, A., Cabral, A.R., Gomes Jr., A.A.S., Neto, A.V.C., Brunetto, W.J., Galbiatti, H., 2014. Depositional age and sediment source of the auriferous Moeda Formation, Quadrilátero Ferrífero of Minas Gerais Brazil: new constraints from $\mathrm{U}-\mathrm{Pb}-\mathrm{Hf}$ isotopes in zircon and xenotime. Precambrian Res. 255, 96-108.

Kohler, E., Anhaeusser, C.R., 2002. Geology and geodynamic setting of Archean silicic metavolcaniclastic rocks of the Bien Venue Formation, Fig Tree Group, northeast Barberton greenstone belt, South Africa. Precambrian Res. 116, 199-235.

Kositcin, N., Krapež, B., 2004. Relationship between detrital zircon age-spectra and the tectonic evolution of the Late Archaean Witwatersrand Basin South Africa. Precambrian Res. 129, 141-168.

Kröner, A., Hegner, E., Wendt, J.I., Byerly, G.R., 1996. The oldest part of the Barberton granitoid-greenstone terrain South Africa, evidence for crust formation between 3.5 and 3.7 Ga. Precambrian Res. 78, 105-124.

Lana, C., Kisters, A., Stevens, G., 2010a. Exhumation of Mesoarchaean TTG gneisses from the middle crust: insights from the Steynsdorp core complex, Barberton granitoid-greenstone terrain South Africa. Geol. Soc. Am. Bull. 122, 183-197.

Lana, C., Tohver, E., Cawood, P., 2010b. Quantifying rates of dome-and-keel formation in the Barberton granitoid-greenstone belt South Africa. Precambrian Res. 177, $199-211$

Lana, C., Buick, I., Stevens, G., Rossouw, R., De Wet, W., 2011. 3230-3200 Ma postorogenic extension and mid-crustal magmatism along the southeastern margin of the Barberton Greenstone Belt, South Africa. J. Struct. Geol. 33, 844-858. 
Lana, C., Alkmim, F.F., Armstrong, R., Scholz, R., Romano, R., Nalini Jr., H.A., 2013. The ancestry and magmatic evolution of Archaean TTG rocks of the Quadrilátero Ferrífero province, southeast Brazil. Precambrian Res. 231, 157-173.

Lancaster, P.J., Dey, S., Storey, C.D., Mitra, A., Bhunia, R.K., 2014. Contrasting crustal evolution processes in the Dharwar craton: insights from detrital zircon $\mathrm{U}-\mathrm{Pb}$ and Hf isotopes. Gondwana Res., http://dx.doi.org/10.1016/j.gr.2014.10.010.

Lowe, D.R., 1994. Accretionary history of the Archean Barberton Greenstone Belt (3.55-3.22 Ga), southern Africa. Geology 22, 1099-1102

Lowe, D.R., Nocita, B.W., 1999. Foreland basin sedimentation in the Mapepe formation, southern-facies Fig-Tree Group. In: Lowe, D.R., Byerly, G.R. (Eds.), Geologic Evolution of the Barberton Greenstone Belt. Geological Society of America, South Africa Special Paper 329, pp. 233-258.

Lubnina, N.V., Slabunov, A.I., 2011. Reconstruction of the Kenorland supercontinent in the Neoarchean based on paleomagnetic and geological data. Mosc. Univ. Geol. Bull. 66 (4), 242-249.

Ludwig, K.R., 2003. User's Manual for Isoplot/Ex, Version 3.0, A geochronological toolkit for Microsoft Excel. Berkeley Geochronology Center Special Publication 4, pp. 73.

Machado, N., Carneiro, M.A., 1992. U-Pb evidence of Late Archean tectonotherma activity in southern São Francisco shield Brazil. Can. J. Earth Sci. 29, 2341-2346.

Machado, N., Noce, C.M., Ladeira, E.A. de Oliveira, O.A.B., 1992. U-Pb geochronology of the Archean magmatism and Proterozoic metamorphism in the Quadrilátero Ferrífero, southern São Francisco Craton, Brazil. Geol. Soc. Am. Bull. 104 1221-1227.

Machado, N., Schrank, A., Noce, C.M., Gauthier, G., 1996. Ages of detritalzircon from Archean-Paleoproterozoic sequences: Inplications for Green-stone Belt setting evolution of a Transamazonian foreland basin in Quadrilátero Ferrífero, southeast Brazil. Earth Planet. Sci. Lett. 141, 259-276.

Manikyamba, C., Naqvi, S.M., Ram Mohan, M., Gnaneswar Rao, T., 2004. Gold mineralisation and alteration of Penakacherla schist belt India, constraints on Archaean subduction and fluid processes. Ore Geol. Rev. 24, 199-227.

Manikyamba, C., Naqvi, S.M., Subba Rao, D.V., Ram Mohan, M., Khanna, T.C., Rao, T.G. Reddy, G.L.N., 2005. Boninites from the Neoarchaean Gadwal Greenstone belt, Eastern Dharwar Craton India: implications for Archaean subduction processes. Earth Planet. Sci. Lett. 230, 65-83.

Mendes, M.C.O., Lobato, L.M., Suckau, V., Lana, C., 2014. In situ LA-ICPMS U-Pb dating of detrital zircons from the Cercadinho Formation, Minas Supergroup. Revista do Instituto de Geociências - USP 14 (1), 55-68.

Menezes, M.G., 1988. Geologia e ocorrência aurífera da faixa Maquiné ao sul da quadrícula de Capanema, Quadrilátero Ferrífero, Minas Gerais. Dissertação de Mestrado. Instituto de Geociências, Universidade de Brasília, 80 p.

Moorbath, S., Taylor, P.N., Jones, N.W., 1986. Dating the oldest terrestrial rocks: fact and fiction. Chem. Geol. 57, 63-86.

Noce, C.M., Machado, N., Teixeira, W., 1998. U-Pb geochronology of gneisses and granitoids in the Quadrilátero Ferrífero (southern São Francisco craton): age constraints for Archean and Paleoproterozoic magmatism and metamorphism. Revista Brasileira de Geociências 28, 95-102.

Noce, C.M., Zucchetti, M., Baltazar, O.F., Armstrong, R., Dantas, E.L., Renger, F.E. Lobato, L.M., 2005. Age of felsic volcanism and the role of ancient continental crust in the evolution of the Neoarchean Rio das Velhas greenstone bel (Quadrilátero Ferrífero Brazil): U-Pb zircon dating of volcaniclastic graywackes. Precambrian Res. 141, 67-82.

Nutman, A.P., 2001. On the scarcity of $>3900 \mathrm{Ma}$ detrital zircon crystals in $>3500 \mathrm{Ma}$ metasediments. Precambrian Res. 105, 93-114

O'Rourke, J.E., 1957. The stratigraphy of the metamorfic rocks of the Rio de Pedras and Gandarela quadrangles, Minas Gerais, Brazil. PhD Thesis. University of Wisconsin, $106 \mathrm{p}$.

Pidgeon, R.T., Wilde, S.A., 1990. The distribution of $3.0 \mathrm{Ga}$ and $2.7 \mathrm{Ga}$ volcanic episodes in the Yilgarn Craton of Western Australia. Precambrian Res. 48, 309-325.

Pullen, A., Ibáñez-Mejía, M., Gehrels, G.E., Ibáñez-Mejía, J.C., Pecha, M., 2014. What happens when $n=1000$ ? Creating large- $n$ geochronological datasets with LAICP-MS for geologic investigations. J. Anal. At. Spectrom. R. Soc. Chem., http:// dx.doi.org/10.1039/c4ja00024b.

Renger, F.E., Noce, C.M., Romano, A.W., Machado, N., 1995. Evolução sedimentar do Supergrupo Minas: 500 Ma. de registro geológico no Quadrilátero Ferrífero, Minas Gerais, Brasil. Geonomos 2, 1-11.
Romano, A.W. 1989. Evolution tectonique de la région NW du Quadrilatère Ferrifère - Minas Gerais, Brésil. Unpublished PhD Thesis. University of Nancy, France, pp. $259 \mathrm{p}$.

Romano, R., Lana, C., Alkmim, F.F., Stevens, G.S., Armstrong, R., 2013. Stabilization of the southern portion of the São Francisco Craton SE Brazil, through a long-lived period of potassic magmatism. Precambrian Res. 224, 143-159.

Rosen, O.M., 2011. Stabilization and breakdown of Archean Cratons: formation of sedimentary basins mafic magmatism, and metallogenic productivity. Geotectonics $45(1), 1-22$.

Rubatto, D., 2002. Zircon trace element geochemistry: partitioning with garnet and the link between U-Pb ages and metamorphism. Chem. Geol. 184, 123-138.

Santos, M.M., Lana, C., Scholz, R., Buick, I., Kamo, S.L., Gerdes, A., Condon, D.J., Corfu F., Tohver, E., Storey, C.D., Basei, M.A.S., Krambrock, K., Fantini, C., 2016. BB zircon - a new Sri Lankan reference material for U-Pb and Hf isotopic laser ablation ICP-MS analysis. Chem. Geol. (submitted for publication).

Schoene, B., De, Wit., Bowring, S.A., 2008. MesoArchean assembly and stabilization of the eastern Kaapvaal craton: a structural-thermochronological perspective. Tectonics 27, 1-27.

Sláma, J., Košler, J., Condon, D.J., Crowley, J.L., Gerdes, A., Hanchar, J.M., Horstwood, M.S.A., Morris, G.A., Nasdala, L., Norberg, N., Schaltegger, U., Schoene, B., Tubrett M.N., Whitehouse, M.J., 2008. Plešovice zircon - a new natural reference material for U-Pb and Hf isotopic microanalysis. Chem. Geol. 249, 1-35.

Stacey, J.S., Kramers, J.D., 1975. Approximation of terrestrial lead isotope evolution by a two-stage model. Earth Planet. Sci. Lett. 26, 207-221.

Storey, B.C., 1995. The role of mantle plumes in continental break-up: case histories from Gondwanaland. Nature 377, 301-308, http://dx.doi.org/10.1038/ $377301 \mathrm{a} 0$.

Takenaka, L., Lana, C., Scholz, R., Nalini Jr., H.A., Abreu, A.T., 2015. Optimization of the in-situ U-Pb age dating method via LA-Quadrupole ICP-MS with applications to the timing of $\mathrm{U}-\mathrm{Zr}-\mathrm{Mo}$ mineralization in the Poços de Caldas Alkaline Complex, SE Brazil. J. South Am. Earth Sci. 62, 70-79.

Taylor, P.N., Kramers, J.D., Moorbath, S., Wilson, J.F., Orpen, J.L., Martin, A., 1991. $\mathrm{Pb}-\mathrm{Pb}, \mathrm{Sm}-\mathrm{Nd}$ and $\mathrm{Rb}-\mathrm{Sr}$ geochronology in the Archean Craton of Zimbabwe. Chem. Geol. 87, 175-196.

Teixeira, W., Carneiro, M.A., Noce, C.A., Machado, N., Sato, K., Taylor, P.N., 1996. Pb, $\mathrm{Sr}$ and $\mathrm{Nd}$ isotope constraints on the Archean evolution of gneissic granitoid complexes in the southern São Francisco craton Brazil. Precambrian Res. 78 151-164.

van Achterbergh, E Ryan, C.G. Jackson, S.E Griffin, W. 2001. Appendix III. Dat reduction software for LAICP-MS. In: Sylvester, P. (Ed.), Laser-ablation-ICP-MS in the Earth sciences, principles and applications. Mineralogical Association of Canada. Short Course Series 29, pp. 239-243.

van Kranendonk, M.J., Kröner, A., Hegner, E., Connelly, J., 2009. Age, lithology and structural evolution of the c. $3.53 \mathrm{Ga}$ Theespruit Formation in the Tjakastad area, southwestern Barberton Greenstone Belt, South Africa, with implications for Archean tectonics. Chem. Geol. 261, 115-139.

Vermeesch, P., 2004. How many grains are needed for a provenance study? Earth Planet. Sci. Lett. 224, 441-451.

Williams, H., Hoffman, P.F., Lewry, J.F., Monger, J.W.H., Rivers, T., 1991. Anatomy of North America: thematic portrayals of the continent. Tectonophysics 187 $117-134$.

Wilson, A.H., Carlson, R.W., 1989. A Sm-Nd and Pb isotope study of Archaean greenstone belts in the southern Kaapvaal Craton South Africa. Earth Planet. Sci. Lett. 96, 89-105.

Woodhead, J.D., Hergt, J.M., 2005. Preliminary appraisal of seven natural zircon reference materials for in situ Hf isotope determination. Geostand. Geoanal. Res. 29, 183-195.

Wu, F.-Y., Yang, Y.-H., Xie, L.-W., Yang, J.-H., Xu, P., 2006. Hf isotopic compositions of the standard zircons and baddeleyites in U-Pb geochronology. Chem. Geol. $234,105-126$

Zeh, A., Gerdes, A., Klemd, R., Barton Jr., J.M., 2008. U-Pb and Lu-Hf isotope record of detrital zircon grains from the Limpopo Belt - evidence for crustal recycling at the Hadean to early-Archean transition. Geochim. Cosmochim. Acta 72, 5304-5329.

Zeh, A., Stern, R., Gerdes, A., 2014. The oldest zircons of Africa-their U-Pb-Hf-O isotope and trace element systematics, and implications for Hadean to Archean crust-mantle evolution. Precambrian Res. 241, 203-230. 